
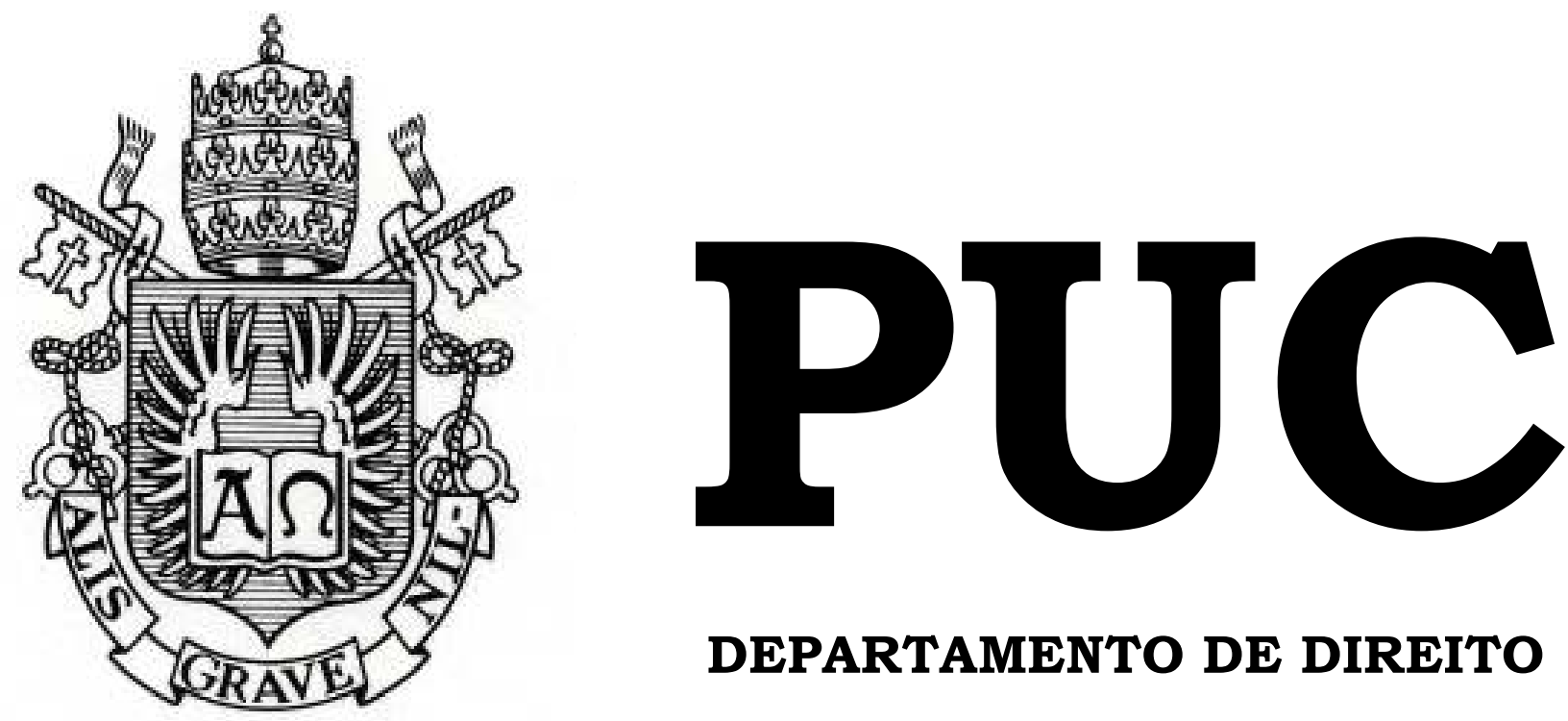

DEPARTAMENTO DE DIREITO

\title{
Direito dos Idosos
}

\section{A Gratuidade nos Transportes Coletivos Urbanos}

$$
\text { Por }
$$

Felipe Lopes Penzin

ORIENTADORA: Regina Soares

2007.2

PONTIFÍCIA UNIVERSIDADE CATÓLICA DO RIO DE JANEIRO RUA MARQUÊS DE SÃO VICENTE, 225 - CEP 22453-900 RIO DE JANEIRO - BRASIL 


\title{
DIREITO DOS IDOSOS
}

\section{A GRATUIDADE NOS TRANSPORTES COLETIVOS URBANOS}

POR

\section{FELIPE LOPES PENZIN}

\begin{abstract}
Monografia apresentada ao
Departamento de Direito da Pontifícia Universidade Católica do Rio de Janeiro (PUC-Rio) como requisito parcial para a obtenção do título de Bacharel em Direito.
\end{abstract}

Orientador: Regina Soares 


\section{Resumo}

Elaboramos este trabalho com o objetivo de avaliar uma questão bastante controvertida nos dias de hoje, que é a participação do Estado no atendimento às necessidades daqueles que compõem a comunidade. Cada grupo tem as suas necessidades, e é papel do Poder Público supri-las de forma a garantir condições de vida digna para as pessoas.

Uma destas formas é a concessão do benefício aos idosos da gratuidade nos transportes públicos coletivos. Com ela, o Estado garante a locomoção dos mais necessitados, ou seja, garantido o direito de ir e vir destas pessoas. Isso faz com que elas se mantenham integradas a sociedade. Este benefício consagra a idéia de ampliar o valor do princípio da dignidade da pessoa humana.

Por causa da idéia de consagração deste princípio, a primeira parte do trabalho aborda os princípios de direito. Dentre eles, destacamos os princípios constitucionais. Os Princípios da Igualdade e da Dignidade da Pessoa Humana mereceram um estudo especial. Procura-se mostrar como tais princípios devem ser aplicados e respeitados na vida dos idosos.

Depois de traçarmos um amplo perfil dos idosos do Brasil. Foi possível verificar como a legislação vigente trata a questão do idoso em nosso país. Por fim, expomos a nossa posição acerca da concessão do benefício da gratuidade nos transportes coletivos, refutando-se os argumentos contrários, apoiados pela posição do Supremo neste caso. 


\section{Sumário}

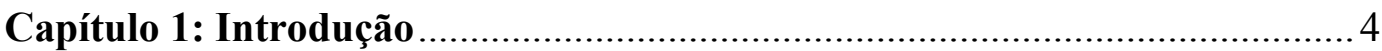

Capítulo 2: Princípios e Regras no Ordenamento Jurídico.............................. 6

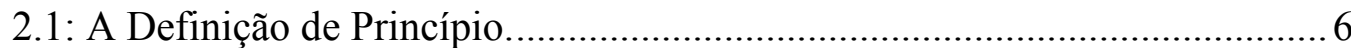

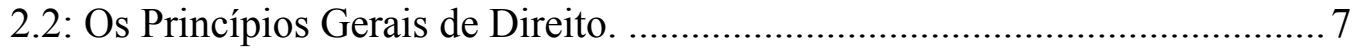

2.3: Os Princípios Positivos ou Princípios Jurídicos............................................. 8

2.4: As Diferenças entre Princípios, Normas e Regras. ..................................... 9

2.4.1: Diferença entre Princípios e Normas ..................................................9

2.4.2: Diferenças entre Princípios e Regras .................................................... 9

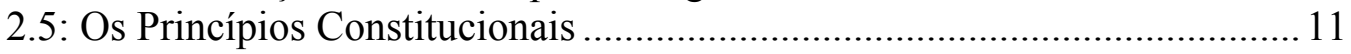

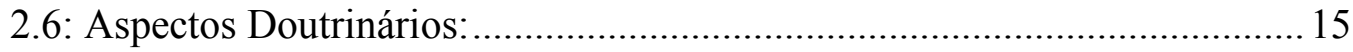

2.6.1: A visão de Celso Antônio Bandeira de Mello ..................................... 15

2.6.2: A Visão de José Afonso da Silva........................................................ 16

2.6.3: A Visão de Paulo Bonavides ................................................................... 17

2.6.4: A Visão de Canotilho. ..................................................................... 18

Capítulo 3: Princípio Constitucional da Igualdade ....................................... 22

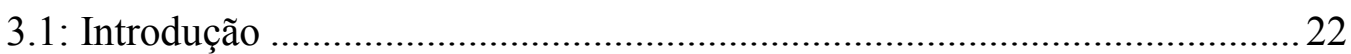

3.2: O Conceito da Igualdade no Ordenamento Jurídico Brasileiro. .................. 22

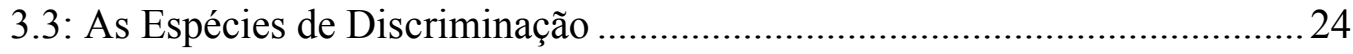

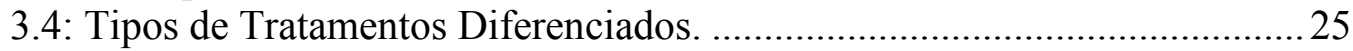

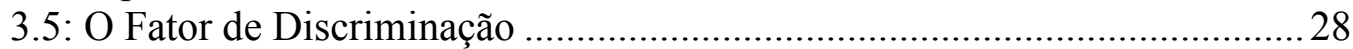

3.6: Conclusões sobre o Princípio da Igualdade. .............................................. 30

Capítulo 4: O Princípio Constitucional da Dignidade da Pessoa Humana .... 32

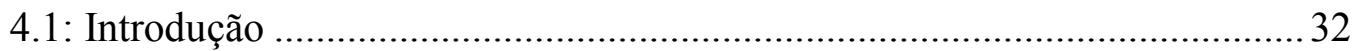

4.2: A Evolução Histórica do Conceito de Pessoa Humana ............................... 32

4.3: Princípio da Dignidade da Pessoa Humana e a Constituição de 1988 ......... 34

4.4: As Ações Afirmativas e o Princípio da Dignidade da Pessoa Humana ...... 37

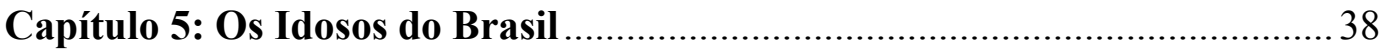

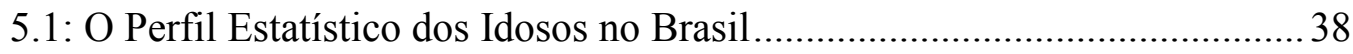

5.1.2: O Fenômeno do Crescimento da População de Idosos.......................... 39

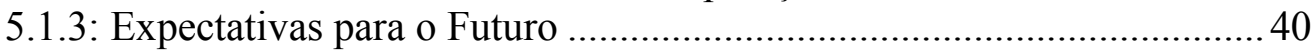

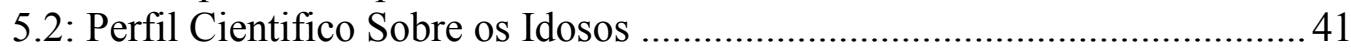

5.2.3: O Conceito de Qualidade de Vida .................................................... 43

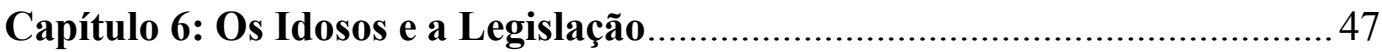

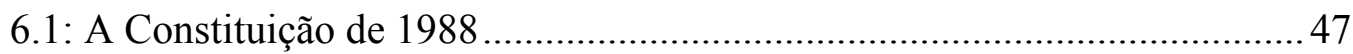

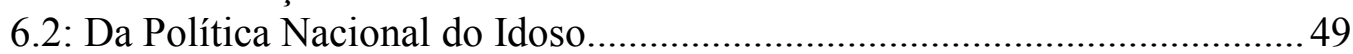

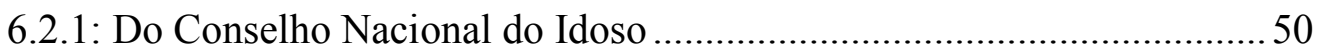

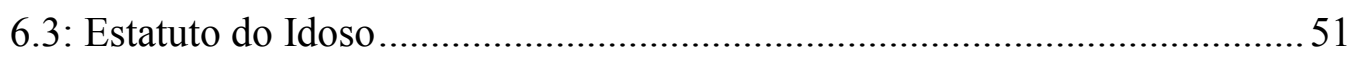

6.4: Aplicação Pratica dos Direitos dos Idosos .................................................. 54

Capítulo 7: A Gratuidade e o Transporte Coletivo ….....................................5 57

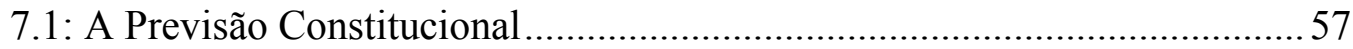

7.2: A Regulamentação da Gratuidade nos Transportes Coletivos.....................59

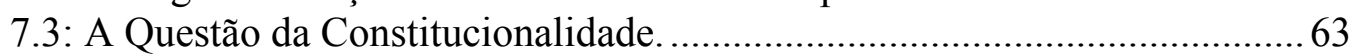

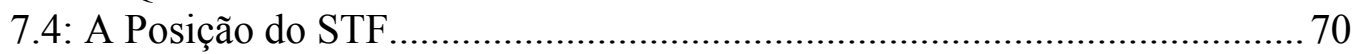

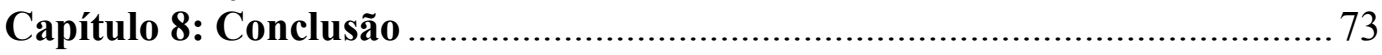




\section{Capítulo 1: Introducão}

O objetivo deste trabalho é abordar um tema que nos dias de hoje é de vital importância para o nosso país. Buscaremos nesta monografia fazer um estudo sobre como o Estado pode agir para melhor regular as relações envolvendo a faixa da população brasileira que, nos dias de hoje, é uma das que mais necessita da atuação estatal no nosso país, que é a faixa dos Idosos.

Para tal situação surge o chamado Estatuto do Idoso (Lei 10.741/03) que veio regular os direitos dos idosos perante a sociedade. Este trabalho monográfico vai mostrar como a criação do Estatuto do Idoso trouxe, em hora mais do que oportuna, uma série de melhorias para as condições de vida da população idosa brasileira.

Com base em uma série de estatísticas trazidas a público pelo IBGE (Instituto Brasileiro de Geografia Econômica) e por outros órgãos da Administração Pública, analisaremos a situação dos idosos em nosso país, para nos mostrar como, de fato, urge regularmos e preservarmos o direito dos idosos brasileiros. Afinal, trata-se da faixa de população que mais aumenta de tamanho nas últimas décadas, reflexo do processo de envelhecimento que a população dos países desenvolvidos ou em vias de se desenvolver, acaba sofrendo. Com o Brasil, este processo não poderia ser diferente. Nosso país, que antes era conhecido como o país do futuro, graças a sua enorme população de jovens e de potencial de crescimento econômico, virou hoje um país de velhos, uma vez que o número de brasileiros ocupando esta faixa de idade está maior que o número de crianças e jovens.

O crescimento da camada de idosos da população brasileira deve abrir os "olhos do Estado" para essa parte da população. Afinal, traz consigo uma série de problemas junto à previdência social, à rede de seguridade social, ao sistema único de saúde. Todos esses aspectos serão abordados em nosso trabalho. 
Assim, fica clara a importância de se ter um Estatuto que venha a regular as condições de vida do idoso brasileiro, assegurando-lhes os benefícios devidos. É exatamente um desses benefícios o responsável por uma enorme polêmica que será o ponto central deste nosso trabalho.

Trata-se do benefício da gratuidade do transporte coletivo para aqueles que pertencem à população idosa deste nosso país. É um benefício constitucionalmente previsto no artigo $230, \S 2^{\circ}$, que afirma que aos maiores de sessenta e cinco anos é garantida a gratuidade dos transportes coletivos urbanos. Este dispositivo é regulado e garantido pelo artigo 39, parágrafo $2^{\circ}$, do Estatuto do Idoso.

A polêmica se da quanto ao fato das concessionárias de transportes públicos coletivos alegarem em juízo a inconstitucionalidade do referido artigo do Estatuto. Muito vem sendo discutido sobre a legalidade da gratuidade do serviço de transporte para os idosos. Diversas Ações Diretas de Inconstitucionalidade foram propostas perante o Supremo Tribunal Federal alegando a inconstitucionalidade do artigo que concede $10 \%$ dos assentos nas linhas de ônibus para os maiores de 60 anos.

Com relação a esta questão tão polêmica, faremos uma análise dos argumentos apresentados tanto por aqueles que alegam a inconstitucionalidade do artigo quanto por aqueles que defendem seu correto posicionamento diante do nosso ordenamento jurídico. Faremos também a nossa análise sobre a questão. Nosso ponto de vista será fundamentado na análise das idéias dos princípios constitucionais, principalmente as que dizem respeito ao princípio da igualdade e ao princípio da dignidade da pessoa humana, princípios estes garantidos pela Constituição de 1988, e que devem estar sempre sobrepostos a qualquer outro argumento contrário.

Para melhor fundamentar nossos argumentos, apresentaremos alguns julgados do STF. Traçaremos comentários acerca do posicionamento desta mais alta corte que através de suas decisões vem definindo novos paradigmas para esta questão. 


\section{Capítulo 2: Princípios e Regras no Ordenamento Jurídico}

\section{1: A Definição de Princípio.}

A definição do termo princípio se refere àquele conjunto de idéias que fundamentam uma pessoa a realizar determinado ato. É através da utilização destes princípios, que fundamentamos e direcionamos as escolhas do dia a dia. Clemente de Diego afirma': "Princípio en General significa cierta Idea de precedencia y procedencia, por lo que se dijo que era origen de alguna cosa". Portanto, o termo Princípio designa a estruturação para um sistema de idéias.

Quanto ao seu aspecto jurídico, o vocábulo princípio pode ter diversos significados. Em sua obra, Crisafulli ${ }^{2}$ considera aquele que afirma ser o princípio, toda norma jurídica considerada como determinante para uma ou muitas outras normas subordinadas. Estas irão se desenvolver através da especificação de seu preceito em direções mais particulares do que os princípios.

Os princípios podem ser divididos em seis categorias distintas ${ }^{3}$. A $1^{\text {a }}$ categoria é conhecida como referente às normas providas de um alto grau de generalidade. A $2^{\text {a }}$ categoria refere-se àquelas normas providas de um maior grau de indeterminação e que por isto só se concretizam por via interpretativa. A $3^{\text {a }}$ classificação se refere às normas de caráter programático. A $4^{\mathrm{a}}$ classificação refere-se a normas de posição elevada dentro da hierarquia das Fontes de Direito. Temos, ainda, o uso do princípio referente às normas que desempenham funções importantes dentro do sistema jurídico ou político unitariamente considerado. Por fim, aplicam o vocábulo princípio para designar normas dirigidas aos órgãos de aplicação

\footnotetext{
${ }^{1}$ ESPINDOLA, Ruy Samuel. Conceito de Princípios Constitucionais. $1^{a}$ ed. São Paulo: Revista dos Tribunais, 1999.p.50.

${ }^{2}$ Apud Eros Roberto Grau. A Ordem Econômica na Constituição de 1988 (Interpretação e Crítica). São Paulo: RT, 1990.336 p.p.117.

${ }^{3}$ ESPINDOLA, Ruy Samuel. Conceito de Princípios Constitucionais. $1^{\mathrm{a}}$ ed. São Paulo: Revista dos Tribunais, 1999.p.56.
} 
cuja função específica é fazer a escolha dos dispositivos ou das normas aplicáveis.

A doutrina tradicional brasileira afirma que os princípios podem ser divididos pelas suas funções dentro do direito brasileiro. São as funções fundamentadora, a função interpretativa e a função supletiva. $\mathrm{Na}$ função fundamentadora os princípios ostentam uma eficácia derrogatória e diretiva, com influência no Direito Publico e Direito Constitucional. Através da função interpretativa, os princípios cumprem o papel de orientarem as soluções jurídicas a serem processadas diante do caso concreto. Por fim, a função supletiva realiza a tarefa da integração do direito, suplementando os vazios da ordem jurídica.

A doutrina tradicional faz a distinção entre dois grupos de princípios. Há uma distinção entre Princípios Gerais de Direito e Princípios Positivos do direito. A diferença principal entre eles consiste no fato dos princípios Positivos serem classificados pela idéia da validade dos fatos, enquanto os Princípios Gerais de Direito são classificados pela idéia de falso ou verdadeiro.

\section{2: Os Princípios Gerais de Direito.}

Os Princípios Gerais de Direito podem classificados de acordo com os atos realizados, sobre os quais irão incidir. Isto é feito através do fundamento das decisões, o que os transforma em princípios positivados através do ato decisional que os veiculou. Portanto, somente através de um ato de decisão de alguma autoridade que o princípio geral de direito em questão sai do aspecto normativo e passa a ser positivado. Isto pode ocorrer de duas formas. Na primeira forma, a positivação decorre da sua origem no direito natural. $\mathrm{Na}$ segunda, nada mais é do que conseqüência do descobrimento destes princípios no interior do Direito Positivo. 
Os Princípios Gerais de Direito encontram expressamente contemplados no artigo $4^{\mathrm{o}}{ }^{4}$ da Lei de Introdução do Código Civil de 2002. São normas iguais as demais. Isto ocorre porque eles são extraídos de normas, pelo procedimento da generalização, já definido nesta obra. Não se pode deixar de concluir que eles teriam também um caráter normativo, já que a função para a qual são abstraídos e adotados é a mesma que de todas as normas.

\section{3: Os Princípios Positivos ou Princípios Jurídicos}

Os Princípios Jurídicos nada mais são do que fruto da aplicação deste conceito geral de princípios,quando aplicados na esfera do Direito,da Ciência Jurídica e do Direito Positivo.

A ciência jurídica usa o termo princípio para classificar os conceitos estruturados sobre o direito positivo, ora para designar determinado tipo de normas jurídicas, ora para construir um tipo especial para todos do grupo. Assim, os Princípios Jurídicos passam a ter uma noção de norma jurídica, funcionando como uma espécie do gênero, o que gera a efetiva normatividade. Os Princípios Jurídicos têm status de norma de direito, ou de norma jurídica. Eles detêm positividade, vinculatividade, sendo normas que obrigam a determinada atuação. Por isso, podem produzir eficácia positiva ou negativa sobre o comportamento público e o comportamento privado, bem como a interpretação e a aplicação de outras normas no caso das regras e de outros princípios derivados de generalização mais abstrata.

Segundo Paulo Bonavides, a juridicidade ou normatividade dos princípios passou pro três distintas fases ${ }^{5}$ : a jusnaturalista, a positivista, e a pós-positivista. A fase jusnaturalista posiciona os princípios jurídicos em esfera abstrata e metafísica. A normatividade dos mesmos, se não era

\footnotetext{
${ }^{4}$ Artigo $4^{\circ}$ da LICC: Quando a lei for omissa, o juiz decidirá o caso de acordo com a analogia, os costumes e os princípios gerais de direito.

${ }^{5}$ Bonavides, Paulo. Curso de Direito Constitucional $5^{\text {a }}$ ed. São Paulo: Catavento, p.232-238.
} 
encarada como nula, ao menos era de duvidosa propriedade praxeológica. São um conjunto de verdades objetivas derivadas da lei divina e humana.

Na segunda fase, chamada de positivista, os princípios entram nos Códigos como fontes normativas subsidiárias dos textos legais. O valor dos princípios jurídicos está no fato de derivarem da lei, e não de um ideal de justiça. Isso torna precaríssima a normatividade dos mesmos, dando um papel meramente subsidiário aos mesmos.

Já a terceira fase, a do pós-positivismo, é a fase em que os princípios são finalmente positivados nos textos constitucionais, de acordo com a compatibilidade das ordens jurídicas aos princípios fundamentais. Desta forma, os princípios ganham imperatividade sobre as outras normas.

\section{4: As Diferenças entre Princípios, Normas e Regras.}

\subsection{1: Diferença entre Princípios e Normas}

São consideradas como categorias pertencentes a tipos conceituais distintos. A diferença entre normas e princípios reside na questão de gênero. As normas só têm eficácia interpretativa tendo, portanto, uma eficácia mais restrita que os princípios. Assim, a norma é um gênero do qual os princípios são espécies.

\subsection{2: Diferenças entre Princípios e Regras}

São várias as diferenças entre princípios e regras. A principal diferença está no fato de que as Regras tem um caráter geral, estabelecidas para um número indeterminado de atos ou fatos, sobre os quais age como reguladora, sendo editada para ser aplicada dentro de uma situação jurídica determinada. Por sua vez, os princípios constitucionais são gerais, porque comportam uma série indefinida de aplicações, estando mais aberto no campo teórico, não sendo aplicado para um caso concreto específico. 
Existe uma teoria, desenvolvida por Dworkin ${ }^{6}$, que foi denominada como Teoria do Tudo ou Nada. Segundo esta teoria, as Regras Jurídicas são aplicáveis por completo, ou não são aplicáveis. Enquanto isso, os Princípios Jurídicos não se aplicam de maneira automática precisando estar presentes as condições previstas como suficientes para que estes princípios possam ser aplicados.

Há uma outra teoria conhecida como a Teoria do Peso e da Importância, considerada uma evolução da Teoria do Tudo ou Nada. Nela, os princípios possuem uma dimensão que não é própria das regras jurídicas. Existem casos em que vários princípios podem ser aplicados à questão, devendo prevalecer aquele que tiver maior importância dentro do ordenamento jurídico e for na teoria,o mais apto para resolver o conflito.

Os Princípios são normas jurídicas impositivas. As Regras são normas que prescrevem imperativamente uma exigência que pode ou não ser cumprida. Os Princípios permitem que os valores, os ideais, estejam em equilíbrio com os interesses envolvidos. Já as regras agem em sentido oposto, pois não há espaço para que exista uma ponderação entre valores ${ }^{7}$. A regra é única, valendo apenas a sua aplicação ao caso concreto, não havendo qualquer tipo de ponderação prévia. Os princípios são normas que tem um grau de abstração elevado, enquanto as regras têm um grau de abstração relativo. Quanto ao grau de determinabilidade, temos que os princípios são vagos e indeterminados enquanto as regras são suscetíveis de aplicação direta. Quanto a ser fundamental ou não, temos que os princípios são normas com papel fundamental no ordenamento jurídico, devido a sua posição hierarquicamente superior, através dos princípios constitucionais. Quanto a proximidade da idéia de direito, temos que os princípios são "Standards" juridicamente vinculantes devido as exigências de justiça e as

\footnotetext{
${ }^{6}$ Apud ESPÍNDOLA, Ruy Samuel. Conceito de Princípios Constitucionais. Revista dos Tribunais, São Paulo, 1999, p. 65

${ }^{7}$ Humberto Ávila contraria este posicionamento ao elaborar uma teoria onde,segundo ele, seria possível uma ponderação de valores entre duas regras,tal qual acontece com os princípios.As regras seriam normas cujas premissas são, ou não,diretamente preenchidas. No caso de conflito,Humberto Ávila afirma que se deve invalidar uma das regras conflitantes ou introduzir uma espécie de exceção.
} 
idéias de direito.Já as regras podem ser normas vinculantes devido ao seu conteúdo meramente formal.

Em um conflito entre princípios e entre regras, podemos perceber duas situações diferentes. A primeira se refere à confrontação das regras entre si. Neste caso, é excluída do sistema aquela regra que seja conflitante à outra norma situada no mesmo plano. Na segunda, a colisão ocorre entre princípios não leva a exclusão de um deles.

O conflito entre os princípios é resolvido na dimensão do peso e não da validade dos princípios. Os princípios colidentes não se excluem, eles apenas se afastam da possibilidade da hipótese colocada no princípio decisório. Afasta-se o princípio cujo peso foi sobrepujado pelo outro. Assim, o aplicador do direito escolhe aquele princípio que seja mais apropriado a questão, ao mesmo tempo em que não elimina do sistema jurídico aquele que é seu rival. Este fica apenas preterido.

\section{5: Os Princípios Constitucionais}

Os Princípios Constitucionais são normas que integram a Constituição com a mesma dignidade de direito que as regras constitucionais ou quaisquer outras normas constitucionais.

Estes princípios atuam como limitadores ao poder de reforma constitucional $^{8}$. Dentro da sede do controle de constitucionalidade, a transgressão aos Princípios Constitucionais enseja inconstitucionalidade da lei ou ato violador.

Os Princípios Constitucionais podem ser classificados como expressos ou implícitos. Os implícitos são normas constitucionais de existência e eficácia pacificamente reconhecidas. Os princípios constitucionais servem para solução de problemas jurídicos que exijam a sua aplicação normativa, funcionando como critérios interpretativos para a

\footnotetext{
${ }^{8}$ Atuando como limitadores ao poder de reforma, a proteção aos princípios constitucionais impede que se altere o texto constitucional de forma que altere direitos garantidos ao cidadão. Desta forma, a única possibilidade de se alterar a constituição mexendo nos princípios constitucionais é para ampliar sua proteção.
} 
solução de outros casos, que não lhes solicitem diretamente a aplicação jurídica. Servem tanto para as normas constitucionais quanto para as normas infraconstitucionais. Eles desempenham funções de normas com diferentes graus de concretização, servindo também como critério para a interpretação de outras normas. Os princípios expressos e implícitos servem de parâmetros para aferição da incompatibilidade da norma objeto com a constituição

A teoria dos Princípios Constitucionais deriva da era pós-positivista. Esta teoria pode ser dividida em três subteorias9": analítico, empírico e normativo.

A Teoria Analítica dos princípios constitucionais se preocupa com a construção de um Direito Positivo, sendo, portanto, indispensável para análise dos conceitos fundamentais (princípio, princípio fundamental e norma).

A Teoria Empírica tem como objetivo principal analisar o modo como os legisladores, os juízes, e a administração pública em todos os seus níveis, observam e aplicam, dentro dos vários contextos políticos e sociais, os princípios constitucionais e a efetividade dos mesmos.

Já a Teoria Normativa cuida da aplicação dos princípios constitucionais, dado que esta pressupõe fundamentação. O rigor dogmático fornece instrumentos de trabalho para compreender o regime jurídico dos princípios constitucionais.

A teoria dos princípios constitucionais serve de alicerce para a compreensão da visão principialista do Direito Contemporâneo. O campo de atuação dos princípios constitucionais é o universo das constituições. É dentro da sua aplicação dentro da disciplina do Direito Constitucional, que estes princípios ganham a sua importância. São os princípios constitucionais que delimitam a eficácia de aplicação do Direito Constitucional.

\footnotetext{
${ }^{9}$ Bonavides, Paulo. Curso de Direito Constitucional 5a ed. São Paulo: Catavento,2005. p.253-257.
} 
Os princípios constitucionais nada mais são que a expressão de políticas fundamentais do Estado e da sociedade, configurando valores éticos, políticos, sociais e ideológico, que servem de alicerce da sociedade e do Estado. $\mathrm{Na}$ teoria dos princípios constitucionais percebemos claramente a sua natureza de norma, de lei e de preceito, mantendo a diferença para os outros, como as normas jurídicas e as regras de direito.

Carmem Rocha consagra a idéia de que os valores firmados pela sociedade são transformados pelo direito. Assim, é a evolução da sociedade, seus posicionamentos, que irão determinar estes princípios. Adotados pelo constituinte, se sedimentam no ordenamento jurídico através de normas que regem as relações jurídicas do Estado. O princípio constitucional define o conteúdo do Direito que deve ser observado nas relações da sociedade.

Para Carmem Rocha os princípios constitucionais são dotados de algumas características ${ }^{10}$ singulares em sua natureza. As características da natureza dos princípios constitucionais são divididas em generalidade, primariedade, dimensão, axiológica, objetividade, transcendência, atualidade, poliformia, vinculabilidade, aderência, informatividade, complementaridade e normatividade jurídica.

-Generalidade: os princípios constitucionais não atuam em hipóteses concretas de relações jurídicas, sendo abordadas sempre em tese.Essa característica de generalidade permite que a Constituição cumpra o seu papel de lei maior do Estado, uma vez que não sendo imutável, não prende a sociedade presa a princípios que não se modificam de acordo com as condições da época. Esta característica permite que os princípios se concretizem dentro daquilo que for preciso.

-Primariedade: Os princípios constitucionais são princípios primários dentro do sistema constitucional, sendo fonte para novos princípios. A primariedade pode ser histórica ${ }^{11}$, jurídica $^{12}$, lógica ${ }^{13}$, ideológica ${ }^{14}$.

\footnotetext{
${ }^{10}$ Apud ESPÍNDOLA, Ruy Samuel. Conceito de Principios Constitucionais. Revista dos Tribunais, São Paulo, 1999, p. 76-84.

${ }^{11}$ Marca a consagração de valores culturais.

${ }^{12}$ É com base nos princípios que derivam todos os julgamentos.
} 
-Dimensão Axiológica: Esta característica deriva do conteúdo ético que adotam. Não são axiomas jurídicos e nem verdades absolutas. Sujeitam-se a mutabilidade sócio-política. Esta característica permite os princípios constitucionais se adaptem as mutações sociais.

-Objetividade: A objetividade deriva da necessidade do aplicador das normas tornar suas idéias explícitas para todos. Com isto, é vedada a possibilidade de interpretações livres. Desta forma,defende-se a sociedade da possibilidade de um ocupante do Estado tomar atitudes baseadas nos princípios constitucionais,sem pensar no bem estar da sociedade garantindo a segurança e a certeza jurídica.

-Transcendência: Os princípios constitucionais superam a elaboração normativa constitucional formal, atingindo a todos dentro da sociedade igualmente.

- Atualidade: Os princípios constitucionais devem ser atuais, de forma que a efetividade e a eficácia das normas constitucionais possam estar garantidas. Deve haver uma compatibilidade entre as bases normativas e as condições sócio-políticas da sociedade. Coerência é a palavra chave na relação entre a aplicação dos princípios constitucionais e as necessidades da sociedade, de acordo com as aspirações do povo para com o ordenamento jurídico.

-Poliformia: A multiplicidade dos princípios constitucionais garante sua efetividade na sociedade.

- Vinculabilidade: Os princípios constitucionais são vinculantes e vinculados. A relação entre os princípios constitucionais e as normas jurídicas se da pela qualidade impositiva, coercitiva que existe entre eles.

-Aderência: Nenhum comportamento estatal poderá divergir ao que foi constitucionalmente positivado nas normas principais. Nem a produção

\footnotetext{
${ }^{13}$ É um complexo de estruturas, instituições e regulamentos se completam e se movimentam dentro do sistema constitucional.

${ }^{14}$ Cria a idéia de Direito dentro do ordenamento jurídico estabelecido
} 
normativa do Estado ${ }^{15}$ ou da sociedade ${ }^{16}$ pode desobedecer aos princípios postos na CF.

-Informatividade: Os princípios constitucionais servem de fontes para todas as ordenações jurídicas. Servem para as instituições jurídicas. Destaca a o caráter fundamental das constituições.

-Complementaridade: Está caracterizada pela construção jurídiconormativa da sociedade estatal. Os princípios constitucionais são condicionantes uns dos outros, se completando nas suas falhas.

-Normatividade Jurídica: Pelo caráter de normatividade jurídica, os princípios são leis, preceitos da regulação abstrata e geral, que diferem das regras, mas que, com elas, são normas jurídicas com imperatividade, vinculabilidade, aplicabilidade como qualquer outra norma dotada de significação de direito.

\section{6: Aspectos Doutrinários:}

\subsection{1: A visão de Celso Antônio Bandeira de Mello ${ }^{17}$}

Em sua obra, Celso Antônio Bandeira de Mello faz uma distinção entre princípios, no sentido geral. Trata-se de um conceito que ocupa o núcleo do sistema jurídico, servindo como verdadeiro alicerce para as relações jurídicas. Violar um destes princípios é mais grave do que transgredir a qualquer outro tipo de norma, afinal, se está ofendendo a todo o sistema que comanda o ordenamento jurídico. Celso Antônio Bandeira de Mello qualifica esta violação como a mais grave ilegalidade ou inconstitucionalidade que se pode cometer, dentro do princípio atingido, voltando-se contra todo sistema, subvertendo valores fundamentais.

Usaremos o brilhantismo de Celso Antônio Bandeira de Melo para analisar o seu pensamento sobre a questão da distinção entre princípios e

\footnotetext{
${ }^{15}$ A produção normativa do Estado é feita através de leis, atos administrativos e sentenças.

${ }^{16}$ A produção normativa da Sociedade é feita através de contratos e convenções

${ }^{17}$ Apud ESPÍNDOLA, Ruy Samuel. Conceito de Princípios Constitucionais. $1^{\mathrm{a}}$ ed. São Paulo: Revista dos Tribunais, 1999, p. 112-116.
} 
regras, como espécies integrantes de um sistema de normas. Celso Antônio Bandeira de Mello reconhece a existência de princípios expressos e princípios implícitos com raízes constitucionais. Diz que em nosso ordenamento jurídico existem certos princípios que são o nascedouro de outros princípios, que a este estão subordinados. Para ele, a Constituição é uma norma jurídica que tem força normativa e efeito vinculador sobre todos os órgãos jurídicos, políticos e administrativos do Estado, sobre a qual devem prestar respeito.

Sobre os princípios constitucionais, o autor reconhece a existência destes, afirmando que os mesmos servem como um dos parâmetros para decidir sobre a constitucionalidade de uma lei ou medidas administrativas, obrigando a interpretação sobre os mesmos a seguir a linha destes princípios.

\subsection{2: A Visão de José Afonso da Silva ${ }^{1819}$}

José Afonso da Silva diferencia a expressão princípios em três sentidos distintos. Afirma que um princípio pode ser uma Norma Constitucional de Princípios, uma Norma Constitucional de Princípios Gerais e, por fim, podem ser Princípios Gerais de Direito Constitucional.

No primeiro caso, os princípios podem ser institutivos e as normas podem ser princípios programáticos. As normas de princípio institutivos são as que o legislador constituinte traça esquemas gerais de estruturação e atribuições de órgãos, entidades ou institutos. Já as normas constitucionais de princípios programáticos são as normas pelas quais o constituinte apenas traçou os princípios a serem cumpridos pelos órgãos administrativos visando a realização dos fins sociais do Estado.

Por sua vez, as normas constitucionais de princípios gerais são normas fundamentais que derivadas de normas particulares e que regulam as relações específicas do dia a dia da sociedade. José Afonso da Silva diz

\footnotetext{
${ }^{18}$ Silva, José Afonso da. Curso de Direito Constitucional Positivo. $16^{\text {a }}$ ed. São Paulo: Malheiros, 1999.p.95-99.

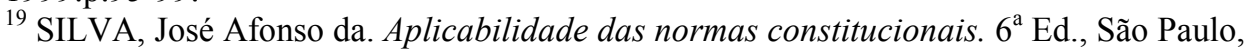
Malheiros, 2003.
} 
que a melhor classificação para estas normas seria chamá-las de normas fundamentais devido ao fato de conter alguns princípios gerais que sustentam todo o ordenamento jurídico nacional. São exemplos os princípios da legalidade e da irretroatividade, normas que devem estar inscritas na Constituição.

Já os princípios gerais de direito constitucional formam uma espécie de conjunto de idéias definidas pelo autor como uma "teoria geral de direito constitucional" uma vez que envolvem conceitos gerais, relações e objetos. A diferença para os princípios constitucionais positivos está no fato de eles não constituírem normas positivas, mas sim princípios que são induzidos por um conjunto de normas.

Sobre os princípios constitucionais positivos, José Afonso os divide em duas categorias. Podem ser princípios político-constitucionais ou princípios jurídico-constitucionais. Os primeiros são formados pelas decisões políticas fundamentais que acabam sendo concretizadas em forma de uma norma dentro do sistema constitucional positivo. Já os princípios jurídico-constitucionais gerais são aqueles que formam a ordem jurídica nacional. Eles decorrem de certas normas constitucionais e de princípios que são derivados dos princípios fundamentais. São exemplos neste caso os princípios da legalidade e da isonomia.

\subsection{3: A Visão de Paulo Bonavides ${ }^{20}$}

Em sua obra, Paulo Bonavides discorre sobre a importância dos princípios gerais de direito. Afirma que os mesmos servem para compreender o Estado de Direito contemporâneo. Para ele, os princípios gerais de direito podem estar presentes no texto constitucional de forma implícita ou explícita. A constitucionalização dos princípios foi de vital importância para compreendermos o Estado de Direito em nosso tempo, além do fato de que o respeito a estes princípios permite uma maior estabilidade dentro do sistema político, impedindo surpresas desagradáveis

${ }^{20}$ Bonavides, Paulo. Curso de Direito Constitucional 5a ed. São Paulo: Catavento, p.232-257. 
de regimes totalitários ou que sejam limitadores das liberdades. Assim, com a constitucionalização destes princípios faz com que as regras do jogo político sejam respeitadas.

Segundo Bonavides, a constitucionalização dos princípios gerais de direito ocorreu em duas fases distintas: a fase programática e a fase não programática. Na primeira, a normatividade dos princípios é mínima, tendo uma aplicabilidade diferida. Na segunda, a normatividade é máxima, atingindo uma dimensão objetiva e concretizadora, na forma de aplicação direta e imediata.

\subsection{4: A Visão de Canotilho. 21}

A doutrina de Canotilho, mestre do Direito Constitucional, afirma que os princípios fundamentais podem ser divididos em duas partes. A primeira é chamada de dimensão constitutiva, pois os princípios constituem uma compreensão global da ordem constitucional. A segunda dimensão é chamada de dimensão declarativa, onde estes princípios são usados para representar a junção de subprincípios e a concretização de normas constitucionalmente plasmadas. O Estado de Direito representa o conjunto destes subprincípios, tais como os princípios da legalidade, da divisão dos poderes, da legalidade da administração, entre outros.

Canotilho entende que tanto os princípios constitucionais estruturantes como os seus subprincípios são juridicamente vinculantes. Estes princípios podem ser percebidos diretamente nos textos constitucionais, como podem ser deduzidos de sua narrativa, bastando estar implícito na idéia que aquele dispositivo quer transmitir. Esta posição dos princípios constitucionais dentro da estrutura do texto constitucional nos comprova a idéia da sua normatividade.

O Sistema Jurídico Brasileiro é definido por Canotilho como um sistema normativo aberto de regras e princípios. Possui a estrutura composta pelas características de disponibilidade e de capacidade de

\footnotetext{
${ }^{21}$ Apud Ruy Samuel Espindola. Conceito de Princípios Constitucionais. $1^{\mathrm{a}}$ ed. São Paulo: Revista dos Tribunais, 1999, p. 172-242.
} 
aprendizagem da norma constitucional, para captar mudanças da realidade a fim de se adaptarem aos conceitos mutáveis daquilo que é garantia de verdade e de justiça. Através das normas, são definidos e aplicados os valores, os programas, as funções que são esperadas para a sociedade. Canotilho classifica o sistema como de regras e princípios, visto que as normas do sistema podem estar sob a forma de princípios ou de regras.

As normas constitucionais são um conjunto de regras e princípios constitucionais que se relacionam de modo sistêmico e estruturante, permitindo a decodificação da estrutura da constituição. Canotilho diz que se o sistema fosse formado só por regras, estaríamos limitando a racionalidade, exigindo uma visão estreita sobre as leis, de tal forma que estaríamos engessando o sistema, não conseguindo adapta-los as necessidades sociais, o que é o verdadeiro objetivo do sistema jurídico nacional. O mesmo defeito ocorreria se o sistema fosse baseado apenas em princípios, já que sem as regras para delimitá-los, estaríamos sempre em conflito para saber qual princípio aplicar ao caso concreto.

Desta forma, torna-se ideal um sistema de princípios e regras. Em casos de conflito, saberíamos quais os princípios constitucionais devem ser usados no caso concreto, de forma a estar atingindo as necessidades da sociedade.

Canotilho, em toda sua obra, reforça a idéia da normatividade dos princípios constitucionais, dizendo ser uma força imediata, pois o mesmo tem caráter regulador para solucionar conflitos na sociedade. A violação de um princípio constitucional pode ensejar recurso extraordinário com base no artigo 102 III, pois os princípios, enquanto normas, enquadram-se na categoria normativa de dispositivo da Constituição.

A Constituição deve ser compreendida como um sistema de normas positivas, e não como uma ordem constitucional reconduzível a valores autônomos em relação aos textos constitucionais. Isto implica que os princípios constitucionais devem ter uma referência positiva, dentro das normas postas. A partir do texto constitucional chegamos aos princípios 
constitucionais. expressos ou implícitos.Não basta que o intérprete constitucional se limite ao ponto de vista normativo.É preciso que os resultados desta interpretação corroborem com o seu pensamento.Princípios expressos ou implícitos derivam portanto do texto constitucional.

Os princípios fundamentais podem ser divididos em três grupos. $\mathrm{O}$ primeiro é o chamado de opções políticas fundamentais conformadoras da constituição $^{22}$. O segundo grupo é dos preceitos que definem ou caracterizam jurídico-constitucionalmente, a coletividade política. ${ }^{23} . \mathrm{O}$ terceiro grupo é dos princípios fundamentais da ordem jurídica constitucional $^{24}$.

Cada um dos princípios fundamentais possui um conteúdo específico de forma a não se confundirem entre $\mathrm{si}^{25}$. Desta forma, os princípios se complementam se condicionam e se modificam reciprocamente, atingindo a cada indivíduo da sociedade. Desta característica derivam os princípios da dignidade da pessoa humana e da autonomia individual, sobre os quais falaremos mais a frente, e a garantia existencial do individuo no plano econômico, social e político que formam o princípio do estado social.

A idéia de força normativa imediata dos princípios constitucionais se traduz no sentido de que os atos jurídicos do poder público ${ }^{26}$ devem estar de acordo com o conteúdo dos princípios constitucionais, sob pena de transgressão ao Direito Constitucional.

Os princípios constitucionais são importantes dentro do ordenamento jurídico nacional. Um dos fatores consiste no fato de ser uma limitação material ao poder de reforma da Constituição ${ }^{27}$. A proteção a estes princípios impede que eles sejam restringidos ou extinguidos da constituição. São classificados como cláusulas pétreas da constituição. Desta forma, estão protegidos contra qualquer tipo de revisão

\footnotetext{
${ }^{22}$ O Princípio da Independência Nacional é um exemplo de princípio baseado em opções políticas fundamentais conformadoras da constituição Princípio da independência nacional

${ }^{23}$ Princípio da cidadania é um exemplo de princípio que representa a coletividade política

${ }^{24}$ Princípio da legalidade é um exemplo de princípio baseado na ordem jurídica nacional

${ }^{25}$ Princípio do Estado de Direito é um exemplo de princípio de conteúdo específico

${ }^{26}$ Leis, sentenças e atos administrativos.

${ }^{27}$ Art.60, parágrafo $4^{\circ}$ da Constituição Federal de 1988.
} 
constitucional. Tal situação protege tanto os princípios constitucionais expressos como os implícitos ${ }^{28}$. Estes princípios não podem ser suprimidos, nem modificados em seu núcleo essencial. É o caso Princípio da Separação de Poderes, Princípio Fundamental do Federalismo, que são protegidos por essa limitação.

Por sua força normativa, os princípios podem servir de fundamento para o controle de constitucionalidade de qualquer lei ou ato normativo. Tanto os princípios explícitos como os implícitos são parâmetros para o juízo de inconstitucionalidade. Todos os atos do Estado e dos poderes públicos devem estar de acordo com as normas e princípios hierarquicamente superiores dentro do texto da Constituição. Os princípios constitucionais também servem ainda, de parâmetro para a revogação de normas de textos anteriores.

Os princípios constitucionais são os caminhos para que as chamadas normas gerais abstratas virem normas específicas concretas através de decisões veiculadas através de procedimentos legislativos, judiciais e administrativos. Aqui, vale lembrar que a norma constitucional delega àqueles que as concretizam ${ }^{29}$ uma possibilidade de determinar como será a sua aplicação. Essa característica é conhecida como discricionariedade.

Desta forma, o texto constitucional permite que se analise o cenário em questão, de forma a não estarem restritos a simples letra da lei. Porém, não se pode ampliar muito este espaço de interpretação, sob pena de se estar criando uma norma inaplicável, o que geraria insegurança jurídica. Assim, quanto maior a abertura a interpretações distintas uma norma constitucional, menor será a densidade que ela terá,deixando de ser um Estado realizável, virando algo abstrato, conflituoso. Quanto mais fechada for a norma, menor será o grau de discricionariedade.

A temática do conflito entre princípios foi abordada por Canotilho como um dos problemas graves dos princípios constitucionais. A Constituição é um sistema aberto de princípios, o que gera conflitos entre os

\footnotetext{
${ }^{28}$ Princípio da Anterioridade Tributária

29 Papel referente ao legislador, o administrador, o juiz.
} 
princípios estruturantes ou entre os princípios constitucionais gerais ou especiais.

Os princípios constitucionais seriam normas jurídicas impositivas e compatíveis com os vários níveis de concretização, de acordo com as condições que envolvem a questão, de forma que os conflitos são solucionados mediante a análise de valores e interesses envolvidos, além do peso e a adaptação à situação dos princípios eventualmente conflitantes. 


\section{Capítulo 3: Princípio Constitucional da Igualdade}

\section{1: Introdução}

Aparentemente, igualdade significa a repetição de características, sejam elas físicas, biológicas, pessoais, ou qualquer outro tipo. Igualdade é a inexistência de diferenças entre dois elementos, quando estes são comparados. Esses elementos podem ser objetos, indivíduos, idéias, conceitos ou quaisquer outras coisas passíveis de comparação. Neste trabalho escolhemos abordar a questão da igualdade quanto aos indivíduos. Abordaremos diversos aspectos,seja na questão de tratamento,seja na questão de oportunidades. Discutiremos os diversos tipos de discriminação que possam existir e como estas discriminações podem trazer um efeito positivo ou negativo para estes indivíduos e para toda sociedade.

\section{2: O Conceito da Igualdade no Ordenamento Jurídico Brasileiro.}

O texto Constitucional no seu artigo $5^{\circ}$ traz, no seu bojo, um dos princípios constitucionais mais importantes do nosso ordenamento jurídico que é o Princípio da Igualdade. O conteúdo deste princípio afirma que todos são iguais perante a lei. Desta forma, busca-se garantir que todos os membros da sociedade sejam tratados de forma semelhante, sem que haja discriminação entre eles.

\footnotetext{
"Artigo $5^{0}$ Todos são iguais perante a lei, sem distinção de qualquer natureza, garantindo-se aos brasileiros e aos estrangeiros residentes no País, a inviolabilidade do direito à vida, à liberdade, à igualdade, à segurança, e à propriedade, nos termos seguintes...."
}

Vale ressaltar que, em alguns casos, um comportamento discriminatório pode trazer algo bom. Nem sempre as discriminações são negativas. Algumas espécies de discriminação podem trazer conseqüências positivas para o discriminado, desde que feitas sem o intuito de prejudicar alguém, procurando apenas aqueles que se adaptam melhor a uma 
determinada situação exigida. Esta diferença entre os efeitos de determinados tipos de comportamento discriminatório é classificada como discriminação positiva e discriminação negativa, sobre as quais comentaremos, neste trabalho, em um tópico específico a seguir.

O significado do Princípio da Igualdade, como teoriza Hans Kelsen ${ }^{30}$, não pode ser apenas restrito à igualdade dos indivíduos perante a lei. A verdadeira significação do princípio da igualdade é da isonomia da própria lei, que deve ser voltada para todos em sua elaboração, e atingir a todos na sua aplicação. Assim, a igualdade garantida pela constituição se refere ao fato de todos terem quer ser obrigatoriamente tratados de maneira idêntica nas normas e nas leis expedidas com base na constituição.

O Princípio da Igualdade impede que as pessoas sejam tratadas de maneira desigual, vistas as condições que se apresentam no caso concreto. A função deste princípio é, portanto, nestes casos em que não se exigem características especiais, que o tratamento dispensado seja o mesmo para todos. Quando o texto constitucional afirma que ninguém deve sofre um tipo de tratamento diferenciado, o legislador está se referindo aquele tratamento voltado para perseguir, prejudicar alguma pessoa ou grupo social distinto.

$\mathrm{O}$ alcance deste princípio não se restringe apenas a nivelar os cidadãos diante de uma norma legal editada. O seu verdadeiro alcance é fazer com este nivelamento entre os cidadãos seja feito na elaboração da lei, que deve se elaborada em conformidade com o Princípio da Isonomia. Assim os legisladores ao pensarem nas leis que estão criando, devem buscar contemplar a todos, com a mesma intensidade e com os mesmos efeitos. A mesma situação deve ser repetida se a lei for elaborada para regular as atividades de certo grupo restrito ${ }^{31}$, onde dentro daquele grupo restrito, todos devem ser atingidos por aquela lei.

\footnotetext{
${ }^{30}$ Apud Celso Antônio Bandeira de Mello. Conteúdo Jurídico do Princípio de Igualdade. São Paulo: Editora Malheiros, 4a Edição, 2005

${ }^{31}$ Exemplo de uma lei que venha a regular a aposentadoria dos trabalhadores rurais.
} 
Conclui-se, portanto que a lei não pode ser fonte de privilégios nem de perseguições, servindo apenas como instrumento de regulação da vida social, regulando equitativamente a todos os cidadãos. Assim, podemos ter a plena certeza que o texto constitucional,quando fala que todos são iguais perante a lei,está se dirigindo não apenas ao aplicador da lei, mas principalmente ao legislador que as elabora.

\section{3: As Espécies de Discriminação}

Como já foi dito anteriormente, o Princípio da Igualdade, na letra da lei, significa que todos devem ser tratados de maneira igual perante as situações do dia a dia. Ocorre que a lei não pode ser levada ao pé da letra em todas as oportunidades. Como já vimos o aplicador do direito tem a liberdade de interpretar a lei de acordo com as condições envolvidas na questão, para então aplicar o melhor direito.

Através de interpretações dos casos concretos, o Princípio da Igualdade passa a ter uma melhor aplicação no direito brasileiro. Com isso, percebemos que nem sempre toda discriminação deve ser vista como algo negativo, podendo muita das vezes, no que soaria contraditório, discrimar algum grupo de indivíduos, com o objetivo de garantir a aplicação do Princípio da Igualdade.

Isto pode ser explicado através dos tipos de discriminação existentes no direito brasileiro ${ }^{32}$. Há a Discriminação Positiva e a Discriminação Negativa $^{33}$. Esta última, todos nós conhecemos, trata-se daquela discriminação que acaba por gerar perseguição imotivada a um indivíduo ou determinado grupo de indivíduos, que acabam sendo prejudicados diante dos demais. Já a Discriminação Positiva ${ }^{34}$ é um tipo de discriminação na

\footnotetext{
${ }^{32}$ Mello, Celso Antônio Bandeira. O Conteúdo Jurídico do Princípio da Igualdade $3^{\mathrm{a}}$ ed. São Paulo: Malheiros, 1993.

${ }^{33}$ Um exemplo de discriminação negativa pode ser mostrado quando se pró́be algum candidato negro de concorrer a uma vaga de emprego simplesmente por se querer que todos os funcionários sejam brancos. Tal situação, não há dúvida, é vedada pelo Princípio da Igualdade.

${ }^{34}$ Um exemplo de discriminação positiva é o caso das cotas raciais nas universidades públicas, que visam suprimir a defasagem entre os que tiveram acesso a escola particular e os que passaram sua
} 
qual se privilegia determinado grupo de forma a suprimir uma situação em que, sem qualquer manifestação externa, já os colocaria em desigualdade com os outros indivíduos, o que já estaria minando a idéia de igualdade buscada no texto constitucional. Tal situação deve ser permitida, pois o grande objetivo do Princípio da Igualdade é garantir a igualdade de condições para todos, seja mantendo a já existente, seja criando essa condição, diante de uma situação desigual.

Aristóteles já antecipava tal teoria ao afirmar que, na verdade, a verdadeira igualdade significa tratar igualmente os iguais e desigualmente os desiguais. Para que se possa aplicar uma das possibilidades de discriminação positiva, nós devemos saber quem são os iguais, quem são os que vivem em desigualdade de condições, quais os critérios de discriminação que podem ser utilizados sem ofender a isonomia, e que tipo de tratamento desigual é permitido sem que haja quebra dos preceitos dos Princípios da Igualdade.

\section{4: Tipos de Tratamentos Diferenciados.}

Ao se elaborar uma lei, cujo objetivo deva ser o de realizar uma espécie de Discriminação Positiva, o legislador deve fazer um amplo estudo sobre a situação envolvida na questão. Deve realizar uma análise criteriosa das características envolvidas para então decidir se ela pode servir como um fato discriminante positivo. Apenas determinados elementos ou características de pessoas ou situações podem permitir um tratamento discriminatório, sem que se esteja ferindo o Princípio da Igualdade.

Devemos entender que não há hipótese que permita qualquer tipo de discriminação,quando esteja envolvendo matéria de raça,sexo ou religião. Isto ocorre, porque o próprio texto constitucional não permite que exista

vida na escola pública, cujo ensino é defasado em relação as demais escolas. Tal situação não é vedada pelo Princípio da Igualdade. 
qualquer tipo de discriminação envolvendo esses critérios. São vários os dispositivos constitucionais que podem comprovar tal afirmação.

Tal situação começa a ser visto no Artigo $3^{\circ}$ da Constituição Federal, que em seu corpo afirma que, dentre os objetivos fundamentais da República Federativa do Brasil consiste o de evitar qualquer discriminação envolvendo raça ou etnia de qualquer indivíduo ${ }^{35}$.

Quanto à questão sexual, o dispositivo que serve de referência para evitar discriminação deste tipo está presente no Artigo $5^{{ }^{36} 6}$.Não é possível se permitir qualquer tipo de tratamento diferenciado entre dois indivíduos por causa da questão sexual.

Já sob o aspecto da questão religiosa, o mesmo Artigo $5^{037}$ serve como prova de que é vedado qualquer tipo de discriminação ligada a aspectos religiosos, quando no seu inciso.

Quando se fala em motivos onde o respeito às crenças religiosas pode ser afastado, estão sendo levantadas hipóteses em que este respeito acaba por atacar outros princípios hierarquicamente mais importantes, caso do direito à vida. Tal situação pode ser exemplificada nos casos das Testemunhas de Jeová, cuja convicção religiosa impede seus seguidores de receber transfusão de sangue em tratamento médico. Tais princípios religiosos não só podem como devem ser afastados por médicos responsáveis pelo tratamento das Testemunhas de Jeová, para que então se respeite o direito a vida dos mesmos. Desta forma, não é atentatório ao Princípio da Igualdade tratá-los de forma diferenciada, visto que tal atitude é feita em nome do Direito a Vida, que deve ser defendido para todos, independentes de crenças religiosas.

Caso exista uma lei com qualquer um destes tipos de discriminação, esta lei estará claramente eivada de inconstitucionalidade, que pode ser

\footnotetext{
35 Artigo $3^{\circ} \mathrm{IV}$ - promover o bem de todos, sem preconceitos de origem, raça, cor, idade, e quaisquer outras formas de discriminação.

${ }^{36}$ Artigo $5^{\circ} \mathrm{I}$ - homens e mulheres são iguais em direitos e obrigações, nos termos desta Constituição.

37 Artigo $5^{\circ}$ VIII - ninguém será privado de direitos por motivo de crenças religiosas ou de convicção filosófica e política, salvo se as invocar para eximir-se de obrigação legal a todos imposta e recusar-se a cumprir prestação alternativa, fixada em lei.
} 
levantada a qualquer momento dentro do sistema de controle de constitucionalidade.

Porém, temos situações em que determinadas características podem ser diferenciadas, sem se estar ferindo o Princípio da Igualdade. Para que isto ocorra, tais discriminações devem estar motivadas em situações, cuja desigualdade entre os grupos concorrentes, ou a especificidade de determinadas situações sejam tão clara, que urge haver algum tipo de tratamento diferenciado, cujo único objetivo,por mais contraditório que pareça,é garantir a igualdade para todos. Nenhuma dúvida quanto a se tratar de uma espécie de discriminação que não ataca ao Princípio da Igualdade

Um tipo de discriminação positiva é a questão das cotas raciais instituída no Rio de Janeiro ${ }^{38}$,e já existe projeto de lei ${ }^{39}$ buscando estender esse benefício a todo o país. Desta forma, o Estado obriga as Universidades Públicas a terem vagas reservadas aos negros e aos que estudaram em toda sua vida no ensino público. Como os estudantes de escolas públicas e os negros têm um nível de educação de base abaixo da média nacional. Através da lei das cotas buscou-se equiparar estes indivíduos aos demais da sociedade, de forma a permitir chances semelhantes de acesso as Universidades Públicas, cujo padrão de ensino é de qualidade.

Outro exemplo de uma discriminação necessária ocorre quando a própria especificidade da situação obriga tal posição. Uma lei que permita a um determinado concurso público contratar candidatos de uma determinada raça, cuja resistência a determinada epidemia possa ser comprovada facilmente. Não se atinge ao Princípio da Igualdade, pelo simples fato de estar se privilegiando um grupo. Devido a especificidade da situação, não se configura um tipo de perseguição. Não se esta privilegiando ninguém, pois a competição para aquela vaga ocorreria entre todos os indivíduos daquela raça, estando em igualdade de condições. Inexiste, portanto, gravame ao

\footnotetext{
${ }^{38}$ Lei n ${ }^{\mathrm{o}} 3.708$, de 9 de novembro de 2001 da Constituição do Estado do Rio de Janeiro.

${ }^{39}$ Projeto de Lei $3627 / 2004$
} 
Princípio da Igualdade quando exista autorização normativa permitindo tal possibilidade.

Conclui-se que independente de quaisquer características existentes em pessoas, coisas ou situações, só serão discriminações aceitáveis aquelas que mantiverem um vínculo entre a peculiaridade diferenciada no objeto e o tratamento desigual determinado. Vale lembrar que a característica escolhida como fator de discriminem não pode nenhuma daquelas presentes no texto constitucional, e aqui citadas anteriormente.

O Princípio da Igualdade busca firmar a idéia da impossibilidade de desequiparações fortuitas ou injustificadas. $\mathrm{O}$ sistema normativo, ao exigir o respeito à igualdade, faz com que a lei deva ser usada pra todos de forma igual, devendo existir uma razão muito valiosa para mudar.

\section{5: O Fator de Discriminação}

Uma lei ou ato atentatório ao Princípio da Igualdade é de fácil percepção. Basta observar-mos o fator de discriminação levantado na questão para vermos se temos uma discriminação positiva ou negativa.

Nas hipóteses positivas há três situações distintas a serem observadas. A primeira diz respeito ao elemento que é tomado como fator de discriminação. A segunda situação se refere a necessidade do elemento tomado como fator de desequiparação estar correlacionado com a disparidade estabelecida pelo tratamento jurídico. Por fim, devemos estar atentos se o produto desta relação entre fator de discriminação e tratamento jurídico diferenciado, é absorvido pelos interesses do Estado.

Assim, devemos observar se o critério usado para discriminar alguém ou algum grupo, deva ser considerado essencial, não havendo outra possibilidade para desfazer a desigualdade pré-existente. Com isso, não basta reconhecer que uma regra de direito é ajustada ao Princípio da Igualdade, apenas quanto a uma situação. Para se respeitar o Princípio da Igualdade, é preciso respeitar todas essas três situações. 
O elemento discriminatório deve estar ligado obrigatoriamente à pessoa, coisa ou situação que deve ser discriminada. Porém, para se permitir a existência de um tipo de discriminação sem se estar atacando o Princípio da Isonomia, a lei ou ato discriminatório não pode se basear em uma característica que seja tão específica, a ponto de singularizar um sujeito dentro do regime particular. Uma lei não pode singularizar de modo absoluto o destinatário ${ }^{40}$.

Ao observarmos a posição doutrinária ${ }^{41}$ sobre o Princípio da Igualdade, fica claro que o mesmo tem como objetivo impedir que se ataquem direitos e garantias fundamentais através de qualquer tipo de perseguição ou favoritismo. Para que as diferenciações normativas possam ser consideradas não discriminatórias, deve existir uma justificativa objetiva e razoável, cuja exigência deve aplicar-se em relação à finalidade e efeitos da medida considerada.

Assim, fica claro que, ao singularizar os efeitos de uma norma discriminatória, impondo o gravame a um só indivíduo, ou atribuindo o benefício a uma só pessoa, está se violando o Princípio da Igualdade. O fator discriminatório, de uma lei ou um ato administrativo, deve atingir a uma categoria de pessoas. $\mathrm{O}$ fator discriminatório não pode buscar atingir a um sujeito determinado, sob pena de estar viciado de preconceito ou perseguição.

Uma regra geral nunca poderá ofender o Princípio da Igualdade pelo aspecto da individualização daquele que deva ser favorecido pela discriminação. Sua incidência é sempre sobre uma categoria de indivíduos. Já uma regra individual pode ou não ser incompatível com a idéia de igualdade. Para tanto devemos observar a espécie de singularização do sujeito. Somente se for direcionada a um sujeito indeterminável é que não se estará ofendendo o Princípio da Igualdade.

Diversas características podem ser destacadas como fatores de

\footnotetext{
${ }^{40}$ Mello, Celso Antônio Bandeira. O Conteúdo Jurídico do Princípio da Igualdade $3^{\text {a }}$ ed. São Paulo: Malheiros, 1993.

${ }^{41}$ Moraes, Alexandre de. Direito Constitucional. 22a ed. São Paulo: Atlas, 2007. p.31-33
} 
discriminação. Podem ser físicas, imunológicas ou de adaptação a determinada especificidade, mas sempre voltadas para um caráter geral,não específico a um determinado sujeito.Os fatores de discriminação são muito semelhantes.Precisamos estar atentos aos detalhes da sua aplicação,para sabermos se é ou não atentatório ao Princípio da Igualdade.

O maior exemplo disso é o fator tempo. Quando uma lei faz referência ao valor tempo, não se está usando o mesmo como fator discriminante. $\mathrm{Na}$ verdade, o fator condicionante é sucessão de fatos ocorridos ao longo deste tempo. Quando uma lei, em seu corpo, específica uma determinada data para uma determinada situação começar, não se está elevando o tempo à condição de discriminadora. Não há uma atuação singular da condição temporal, e sim dos fatos ocorridos neste intervalo.

É o que ocorre com os concursos públicos. A diferenciação entre os candidatos que preenchem ou não determinados requisitos é o fator discriminante e não o tempo do concurso. Afinal, este é igual para todos. $\mathrm{O}$ fator tempo significa a extinção de uma sucessão reiterada de fatos.

Conclui-se que a lei não pode tomar o tempo como fator de discriminação entre pessoas a fim de colher tratamentos diferentes para elas, sem ir contra ao princípio da igualdade. O elemento discriminador será sempre um fato ocorrido neste tempo determinado. As diferenças de tratamento só se justificariam diante de fatos e situações diferentes.

\section{6: Conclusões sobre o Princípio da Igualdade.}

O ponto principal de uma regra, perante o princípio da isonomia, reside na necessidade de se ter uma correlação lógica entre o fator escolhido como critério de discriminação e o ato de discriminar. Uma discriminação pode ser reconhecida como positiva, quando ajudar a equilibrar uma situação até então desigual.

A validade de uma regra perante o Princípio da Igualdade está ligada ao fator de discriminação.As diferenciações não podem ser feitas com quebra do preceito da igualdade.A Constituição veda expressamente 
qualquer tipo de preconceito ou perseguição.A aplicação do critério escolhido como fator diferenciado deve ser justificada através de um tratamento jurídico específico justificado pela desigualdade já existente.

Uma discriminação só estará de acordo com o Princípio da Igualdade quando cumprir alguns elementos fundamentais. A discriminação não pode atingir apenas um indivíduo. As situações ou pessoas discriminadas devem ser distintas entre si. Deve ainda ter uma correlação lógica entre os fatores diferenciadores e o interesse constitucional que se visa proteger.

Circunstâncias ocasionais, casos fortuitos, acidentais ou simplesmente pequenas distinções entre categorias de pessoas não podem ser consideradas discriminações positivas. Não é qualquer pressuposto fático ou fundamento racional que pode ser considerado como fator discriminatório compatível com princípio igualitário.

Não há duas situações tão iguais que não possam ser distinguidas como não há duas situações tão distintas, onde não se possa encontrar um ser denominador comum $^{42}$.Para haver uma discriminação positiva, é importante que a diferenciação seja relevante. A Igualdade, sendo uma presunção absoluta do texto constitucional, se consagra como maior garantidor de direitos individuais. É a defesa deste princípio que devemos objetivar, pois a busca de uma sociedade igual é o caminho para uma vida melhor para todos.

\footnotetext{
${ }^{42}$ Mello, Celso Antônio Bandeira. O Conteúdo Jurídico do Princípio da Igualdade $3^{\mathrm{a}}$ ed. São Paulo: Malheiros, 1993.
} 


\section{Capítulo 4: O Princípio Constitucional da Dignidade da Pessoa Humana}

\section{1: Introdução}

A cada dia que passa, ao observamos as relações sociais do dia a dia, tanto no Brasil como no Mundo, vemos a necessidade de resgatar o Princípio da Dignidade da Pessoa Humana. Vivemos em um mundo onde o respeito ao seu semelhante é cada vez mais esquecido. Esse desrespeito à pessoa acaba servindo de fonte para violência e para diversos conflitos, os quais somos obrigados a assistir. Desta forma, se torna cada vez mais necessário resgatarmos os valores humanos de forma que possamos criar um novo ambiente, onde o respeito ao ser humano e, correlatamente, aos seus direitos servirá de base para dias melhores. Com base neste pensamento, passaremos a traçar um rápido perfil da evolução do conceito de pessoa humana durante a história.

\section{2: O Conceito Histórico de Pessoa Humana}

O conceito de pessoa humana é um conceito de origem recente na história. Para comprovar tal definição basta analisarmos os períodos históricos para percebermos que só recentemente (obviamente levando em conta o tempo histórico) tal conceito veio a se fortalecer, permanecendo importantíssimo nos dias de hoje, e obviamente para o futuro.

Dentro da Grécia Antiga, o homem era considerado apenas um animal político. Aristóteles afirmava que o homem era um animal destinado a viver em sociedade. Tal situação aconteceria pelo fato dele ser um animal diferenciado dos outros, pois sendo detentor do dom da palavra, tem o poder de usar o discurso de forma a facilitar o entendimento entre eles. Assim, podiam entender o que é útil e o que é prejudicial, o que é justo e o que não é. Esta característica foi o embrião para constituição do Estado.

A idéia de dignidade da pessoa humana apareceu através do estoicismo, mas se desenvolveu fortemente com o advento do Cristianismo. 
Na definição dos Estóicos, a dignidade humana é uma qualidade inerente ao ser humano. Esta característica exclusiva do ser humano os distinguia dos outros animais, seguindo o mesmo caminho das idéias de Aristóteles.

Porém foi com o surgimento do Cristianismo, que a idéia de dignidade da pessoa humana, confirmada pela obrigatoriedade do seu respeito, acabou se fortalecendo. Afinal, o pensamento cristão é baseado na idéia de que todos nós somos filhos de Deus. Nada mais justo de que todos os seus filhos se respeitem, na integra de suas características e seus direitos, uma vez que fomos feitos à imagem e semelhança do criador ${ }^{43}$. Com isso, ao respeitarmos uns aos outros, estaremos respeitando indiretamente ao próprio Deus. Assim, ao violar a dignidade da sua criatura, estaríamos violando a dignidade do próprio criador.

O princípio da dignidade da pessoa humana foi evoluindo ao longo dos séculos, muito ligado ainda ao aspecto religioso. Neste aspecto, destacam-se grandes pensadores como Tomás de Aquino, durante a Idade Média. Somente na Idade Moderna é que veio a ser pensado esta questão fora dos aspectos religiosos. Os pensadores desta época incluíram o aspecto ético na discussão ao afirmar que o Homem deve sempre se portar com ética e respeito aos seus semelhantes, ainda que aquela situação lhe venha causar prejuízo, pois o respeito ao seu semelhante deve ser sempre a prioridade.

Porém, de todos que pensaram o princípio da dignidade da pessoa humana, o destaque dos pensadores modernos foi o grande Immanuel Kant. Sua principal contribuição foi à idéia definida por Imperativo Categórico. Uma das conseqüências deste seu pensamento foi a afirmação de que o Homem seria um fim em si mesmo, e não pode ser tratado como animal ou ser coisificado. Para Kant, o conceito de dignidade deriva exatamente dali, pois as coisas sempre terão um preço, ou então podem ser trocadas facilmente. Não é vital que se conservem as coisas. Já as pessoas, elas não têm preço. Elas são insubstituíveis e devem ser respeitadas dentro de suas

\footnotetext{
${ }^{43}$ Gênesis 1.27
} 
relações, uma vez que cada ser humano é único, dentro das suas individualidades. Nós devemos respeitar as características de cada um. Kant define isto como o verdadeiro conceito de dignidade.

Foi com os horrores da Primeira e da Segunda Guerra Mundial, que o mundo abriu os olhos para a importância de se valorizar o respeito ao ser humano. Alguns regimes ditos como democráticos,mas que na verdade eram repressores,utilizavam-se de forma enganosa deste princípio para justificar seus atos.Vale lembrar que o Princípio da Dignidade Humana estava presente no AI-5, ato mais hostil aos valores humanos,prestados pela ditadura militar de 1964 no Brasil.

Mesmo com estes percalços, a violência e o desrespeito com os valores humanos eram tão grande, que urgia a necessidade de uma atitude contra tal falta de respeito. Foi então que o princípio da dignidade da pessoa humana começou a ser constitucionalizado no Brasil e no mundo. $\mathrm{O}$ ápice deste processo foi sua positivação na Declaração Universal dos Direitos Humanos das Nações Unidas

\footnotetext{
"Artigo $1^{\circ}$ : Todos os seres humanos nascem livres e iguais em dignidade e direitos. Dotados de razão e consciência, devem agir uns para com os outros em espírito e fraternidade."
}

\section{3: Princípio da Dignidade da Pessoa Humana e a Constituição de 1988}

Seguindo os passos dos outros países, a Constituição Federal de 1988 constitucionalizou o princípio da dignidade da pessoa Humana. Foi dada tal importância para este princípio dentro do texto constitucional que o mesmo foi protegido como cláusula pétrea, no artigo 60 IV da Constituição Federal de 1988. Sendo assim, não pode ser alterado nem por Emenda Constitucional, salvo se for para aumentar a sua proteção. Tal é a importância dada a este princípio, que ele se encontra inserido logo no 
primeiro artigo do texto constitucional ${ }^{44}$,sendo definido como um princípio fundamental da república.

O princípio da dignidade da pessoa é de tal importância dentro da ordem constitucional brasileira, que acaba servindo de base para outros dispositivos. É pensando neste princípio fundamental que a constituição garante aos presidiários brasileiros que eles cumpram suas penas em estabelecimentos que respeitem a sua integridade física e moral, onde os presos seriam separados pela gravidade do seu delito, o que permitiria maiores condições para o que seria o verdadeiro objetivo do sistema carcerário brasileiro ${ }^{45}$.Pena que tal disposição não vem sendo cumprida em nosso país, pois o cenário que vemos são carceragens super lotadas e condições degradantes de higiene, mostrando como o Estado consegue violar um princípio fundamental da própria República.

Outros dispositivos constitucionais baseados no princípio da dignidade da pessoa humana estão espalhados no texto constitucional. É pelo respeito à dignidade humana que a constituição criminalizou a prática do racismo,de tortura,e outros que atentem contra a integridade humana ${ }^{46}$.

Reforçando a idéia da sua importância dentro da necessidade de valorizar o ser humano, a Constituição traz uma série de dispositivos regulando as relações sobre família,sobre a criança e o adolescente, e sobre o idoso.Estes artigos,consagrados como direitos sociais, trazem em seu bojo os direitos destes grupos sociais ${ }^{47}$.

É com base no princípio da dignidade da pessoa humana ,de forma que se respeitem os valores humanos,que o Estado vem a atuar, através de alguns dispositivos, para garantir condições essenciais ao ser humano.São condições essenciais como saúde,alimentação,educação,lazer,e o bem estar das crianças ,dos idosos,da família brasileira.

\footnotetext{
44 “Artigo 1": A República Federativa do Brasil, formada pela união indissolúvel dos Estados e Municípios e do Distrito Federal, constitui-se em Estado Democrático de Direito e tem como fundamentos". IV - a dignidade da pessoa humana

${ }^{45}$ Artigo $5^{\circ}$ XLVIII e XLX da CF de 1988

${ }^{46}$ Artigo $5^{\circ}$ XLII e XLIII

${ }^{47}$ Artigo 226,parágrafo $7^{\circ} \mathrm{c} / \mathrm{c}$ Artigo 227 e Artigo 228
} 
A constitucionalização deste princípio, fundamento de tantos outros princípios constitucionais, objetivou protege-los dentro do ordenamento jurídico nacional, a fim de garantir uma efetividade cada vez maior ao princípio. Em nossa leitura, o conceito de dignidade objetivado pela constituição é o de uma qualidade intrínseca de todos os seres humanos das quais derivam direitos e deveres que possibilitem a cada ser humano viver em condições dignas, garantindo condições dignas de coexistir dentro de uma sociedade. Assim,quando um indivíduo respeitando a integridade e as condições existenciais dos demais,recebe de volta o mesmo respeito. Com isso, está constituída uma sociedade harmônica em seu funcionamento.

Assim, qualquer ato que seja de cunho degradante ou desumano estará ofendendo o princípio da dignidade. Não importa se o ato violador provenha de um Estado ou de um particular, qualquer um que atente contra os valores humanos, o impedindo de uma vida digna, estará violando o princípio da dignidade da pessoa humana. A professora Maria Celina Bodin, em sua brilhante obra entende como desumano tudo aquilo que possa tirar valores de uma pessoa, tornando-a com o mesmo valor de uma coisa, e por isto, atentatório a dignidade da pessoa humana ${ }^{48}$.

Com o entendimento do princípio da dignidade da pessoa humana como um princípio fundamental da República, o Estado é obrigado a tomar dois tipos de posicionamento diferente perante os valores humanos. De um lado, o Estado deve atuar para promover ações que viabilizem a efetivação dos valores humanos, criando totais condições de uma vida digna para todos. Assim, estará respeitando o princípio constitucional da igualdade. De outra forma, o Estado deve tomar atitudes para proteger os seus membros de possíveis violações a estes valores. Deve proteger contra qualquer tipo de agressão ou tratamento desumano que afete estas condições de vida digna, situação explicada anteriormente.

Toda esta atuação faz parte dos deveres do Estado para com a sua sociedade. Esses deveres existem porque as pessoas devem sempre estar

\footnotetext{
${ }^{48}$ MORAES, Maria Celina Bodin de. Danos a pessoa humana: uma leitura civil-constitucional dos danos morais. Rio de Janeiro: Renovar, 2003, p. 85.
} 
acima do Estado e de seus governantes. O Estado existe em função de seu povo, e não o contrário. São as pessoas que constituem o valor maior da democracia, e não o mero poder. $\mathrm{O}$ valor das pessoas acaba atuando como um fator estruturante para definir o conceito de Estado de Direito. Só atinge verdadeiramente este conceito, aquele que respeita os direitos de seus cidadãos. Tais argumentos mostram porque não cabem nos dias atuais governos absolutistas, autoritários, que desrespeitem ao povo, ofendam a sua liberdade, os seus valores, e por conseqüência a sua dignidade.

\section{4: As Ações Afirmativas e o Princípio da Dignidade da Pessoa Humana}

Repetindo o que foi dito no capítulo sobre o princípio da igualdade, o princípio da dignidade da pessoa humana também serve de fundamento de justificativa para o Estado intervir em situações de desigualdade entre indivíduos ou grupos sociais.

As ações afirmativas consistem em ações do Estado para corrigi-la uma forma específica de desigualdade que esteja a ela associada por determinadas características biológicas ${ }^{49}$ ou sociológicas ${ }^{50}$ que marquem ou diferenciem a identidade de certos grupos na sociedade.

Existem diferenças que marcam a aplicação do princípio da igualdade e o princípio da dignidade da pessoa humana como fundamento para as ações afirmativas estatais. O Princípio da Igualdade atua nas ações afirmativas garantindo que nenhuma ação ou omissão do Estado objetive perseguir um indivíduo ou certo grupo de pessoas, e sim para garantir que todos tenham condições e oportunidades iguais dentro da sociedade. Já o princípio da dignidade da pessoa humana é fundamento para as ações afirmativas, pois estas existem apenas para garantir condições dignas. Estes princípios irão reaparecer na discussão sobre a constitucionalidade do benefício da gratuidade para os idosos nos transportes públicos coletivos.

\footnotetext{
${ }^{49}$ São características biológicas a Raça e o Sexo

${ }^{50}$ São características sociológicas a etnia e religião
} 


\section{Capítulo 5: Os Idosos do Brasil}

\section{1: O Perfil Estatístico dos Idosos no Brasil}

O Estatuto do Idoso, logo em seu artigo $1^{\circ}$ traz a definição do que seja uma pessoa idosa para o direito brasileiro. De acordo com a redação do mesmo, esta definição se refere àquelas pessoas que tenham idade igual ou superior a 60 (sessenta) anos.

A população brasileira está envelhecendo. Esta é uma afirmação que podemos fazer ao analisar os últimos censos demográficos levantados pelo IBGE $^{51}$. No Censo realizado no ano de 1991, foram contabilizados exatos 10.722.705 idosos. Já no Censo realizado no ano de 2000, foram contabilizados 14.536.029 de pessoas nestas condições. Em 2006 este número atingiu 19 milhões de pessoas. O número de idosos, que em 1991, representava $7,3 \%$ da população brasileira, em 2000 passou a representar 8,6 \% da população e ficou em 10\% da população em 2006

Ao explicar o processo de envelhecimento que a população brasileira vem sofrendo nas últimas décadas, podemos traçar como estes idosos se distribuem pelas regiões brasileiras. Analisando as estatísticas apresentadas pelo IBGE, vemos que em 2006, os idosos representavam $11 \%$ da população do Sudeste, $10,7 \%$ da população do Sul, $6,2 \%$ da população do Norte, $9,2 \%$ da população nordestina e $7,8 \%$ da do Centro-Oeste.

Quanto as Estados, temos que Rio de Janeiro e Rio Grande do Sul são aquelas que apresentam a maior concentração de idosos do país, com respectivamente $13,5 \%$ e $12,3 \%$ da população total nesses municípios. Em contrapartida, os Estados de menor população idosa são Roraima e Amapá que tem respectivamente $4,7 \%$ e $5,0 \%$ cada.

Outro dado interessante que mostra o envelhecimento cada vez mais rápido da população brasileira se refere aos dados de que em comparamos o número de idosos da década de oitenta, com o número de crianças no

\footnotetext{
${ }^{51}$ Instituto Brasileiro de Geografia e Estatística- Dados dos Censos 1991 e 2000 e da Síntese de Indicadores Nacionais de 2006
} 
mesmo período. Em 1980 existiam 16 idosos para cada 100 crianças. Já em 2000, este número passou a ser de quase 30 idosos para cada 100 crianças.

\subsection{2: O Fenômeno do Crescimento da População de Idosos}

Diversos fatores podem ser apontados como responsáveis por esta mudança de perfil na composição da sociedade brasileira e que serão brevemente indicados neste trabalho.Um dos principais fatores está ligado ao progresso nos métodos científicos e médicos, que permitiram o avanço na qualidade do atendimento médico, para quem possui este privilégio, dentro de um país tão desigual quanto o nosso. Assim, novos tratamentos descobertos permitem que se aumente a expectativa de vida do cidadão brasileiro.

Um exemplo disso está no fato que a expectativa de vida do brasileiro já atinge 71,9 anos. Trata-se de um número, que se não é o ideal (países desenvolvidos como o Japão atingem uma expectativa de vida em torno de 81 anos), representa uma melhoria rápida destes indicadores, pois no ano de 2000 este número era de 68 anos, o que representa quase quatro anos a mais de vida, em expectativa, ganho em menos de uma década. Se fôssemos mais longe, levando estes números para a década de 80 , veremos que, o aumento da esperança de vida do brasileiro foi maior: chegou a 9,1 anos ao passar de 62,6 anos para os atuais 71,7 anos. Segundo o IBGE, ao longo de 24 anos, a esperança de vida ao nascer no país cresceu anualmente cinco meses em média.

$\mathrm{O}$ segundo fator também tem como fonte as mesmas idéias, porém vai no sentido oposto. Se o crescimento econômico trouxe melhorias na saúde que propiciaram um aumento da expectativa de vida, do outro trouxe um custo de vida muito alto para as famílias. Assim, muitas delas acabam por adotar um planejamento familiar mais rigoroso,que acaba por diminuir o número de filhos por casal,o que afeta diretamente a taxa de natalidade do país,o que é um fator marcante para este sentido envelhecimento de nossa 
população. Em 1992 houve 23 nascimentos por cada grupo de mil habitantes. Em 2001, este número caiu para 20,9 por cada mil habitantes. Se olhar-mos apenas para a taxa de fecundidade bruta veremos que em 1991 era de 2,7 filhos por mulher. Esse número caiu para 2,4 filhos por mulher no ano 2000 .

Podemos ainda acrescentar um terceiro fator, menos influente, mas que acaba repercutindo nossas estatísticas. Referimos-nos ao crescimento constante da criminalidade, que acaba por atingir em maior grau a faixa jovem da população brasileira, o que proporcionalmente acaba por afetar a porcentagem que as camadas de crianças, jovens, adultos e idosos representam da população brasileira.

\subsection{3: Expectativas para o Futuro}

Os problemas que o avanço do número de pessoas que ocupam a faixa da terceira idade nos dias de hoje precisam ser postos em preferência, quanto à atenção de todos os Estados, não apenas ao Estado Brasileiro. Esse é um problema que se reflete no mundo todo.

Segundo estimativas da Organização Mundial de Saúde (OMS),esta previsto que, lá pelo ano 2025, pela primeira vez na história teremos mais idosos do que crianças no planeta. E o Brasil não fica atrás. Afinal, estudos do IBGE mostram que, nos próximos 20 anos, a população idosa do Brasil poderá ultrapassar os 30 milhões de pessoas e deverá representar quase 13\% da população ao final deste período, o que segundo a OMS, nos torna o sexto país com o maior número de idosos do mundo.

O idoso é um indivíduo discriminado pela sociedade brasileira. Ao atingir certa idade (algumas vezes até mesmo inferior ao conceito que determina a classificação sobre quem é idoso), essas pessoas acabam fora do mercado de trabalho, perdendo sua fonte de sustento. O que afeta em geral a situação econômica das pessoas idosas é a perda de contato com a força de trabalho, a obsolescência de suas atividades, a desvalorização de 
seus vencimentos e pensões e a pobreza generalizada da sociedade, no mundo.

\section{2: Perfil Cientifico Sobre os Idosos}

A ampliação do número de idosos que compõe a sociedade brasileira fez com que fosse cada vez mais necessária a atuação do Estado para garantir os direitos para esta faixa da população. Cabe ao Estado agir de forma que as pessoas acima de 60 anos possam ter um fim de vida digno, após tanto contribuírem para a evolução da nossa sociedade.

Todo homem,quando está na flor de sua idade, contribui com o seu trabalho dentro da sociedade, produzimos riquezas, pagamos nossos impostos. Porém, esta situação não é eterna, e respeitando as leis da natureza, os homens acabam envelhecendo, e entrando numa fase em que passam a necessitar de uma série de cuidados.

Tais cuidados, porém, não são tarefa apenas do Estado. Tal responsabilidade também deve ser dividida entre as famílias dos idosos e os membros da sociedade em geral, que devem prezar respeito pelos mais velhos, que tanto prestaram para que aquele lugar onde vivem fosse construído.Desta forma,deve se buscar que os idosos,ao saírem do mercado de trabalho continuem inseridos na comunidade.Assim, estarão sendo garantidas suas condições de bem-estar e garantida a dignidade do resto de seus dias de vida.

Nas análises estatísticas feitas anteriormente, pudemos constatar que a taxa de crescimento da população idosa no mundo é maior que a taxa de natalidade em nosso planeta. Assim, todos passam por um fenômeno de envelhecimento da população. Como não poderia deixar de acontecer, o Brasil, ainda que atrasado como sempre, é um reflexo deste fenômeno. Expectativas mostram que nos próximos anos o número de idosos no Brasil já vai ser maior que o número de crianças. Esta situação nos leva à necessidade de um avanço nos estudos de apoio as pessoas mais velhas, para os quais dedicaremos este espaço. 
Existem dois tipos de ciência que analisam a questão dos idosos. São a Geriatria e a Gerontologia ${ }^{52}$. A Geriatria serviu de base para a concepção da idéia de Gerontologia. Porém, nos parece importante diferenciarmos estas duas ciências. Ambas tratam da questão dos idosos, mas com abordagens diferentes. Uma aborda a questão dentro dos aspectos médicos, enquanto a outra aborda os aspectos científicos da questão.

A Geriatria é o grupo da medicina que cuida dos idosos. Seu objetivo básico é desenvolver uma série de pesquisas para atuar não apenas na cura das doenças típicas dos idosos, como para descobrir formas de prolongar a vida destes. Assim, fazendo a prevenção deste cedo, estamos aumentando nossas condições de saúde e cada vez mais esticando nossa expectativa de vida. As doenças mais comuns aos idosos estão ligadas aos problemas pulmonares (frutos do fumo em excesso) e aos casos de câncer. Cabe a Geriatria desenvolver técnicas que descubram curas para estas doenças. O desejo, ainda que utópico, é o de esticar a vida de seus pacientes o máximo possível. Vida esta que deve ser a mais saudável que se possa conseguir.

A Gerontologia é uma ciência que vai se dedicar ao estudo do processo de envelhecimento humano. O objeto da gerontologia é saber como a personalidade e a conduta do homem vai se adaptando e mudando com o processo de envelhecimento. Aborda a questão quanto a critérios psico-sociais e biológicos. Trata-se, portanto, de uma ciência que interage com outras ciências como a Sociologia e a Antropologia.

Como foi dito anteriormente, a Gerontologia envolve aspectos sociológicos, médicos e físicos. Já a Geriatria estuda o processo do envelhecimento. Enquanto uma analisa os aspectos biológicos e tudo que envolve esta fase da vida humana, a outra vai estudar apenas os aspectos de saúde dos idosos, tanto no aspecto de tratamento como de prevenção.

Quanto às semelhanças envolvendo estas duas ciências, vemos o aspecto do foco em questão.Ambas objetivam, por caminhos transversos, a obtenção de qualidade de vida para os idosos. Estas ciências acreditam que

\footnotetext{
${ }^{52}$ Revista Brasileira de Ciências Sociais, nº 43, junho de 2000
} 
o caminho para a efetivação de todos os direitos pertencentes a esta faixa etária da população está relacionado a uma vida digna. É sobre este tema que passaremos a falar em seguida.

\subsection{3: O Conceito de Qualidade de Vida}

Não é fácil definir o que é qualidade de vida. Vale lembrar que todos os homens têm as suas individualidades, e isto deve ser respeitado. Assim, nem sempre o que é bom para um determinado indivíduo é bom para os demais.

No caso dos idosos, em nossa opinião, a qualidade de vida só é alcançada enquanto os mesmos estão integrados à sociedade. Não basta que eles tenham acesso à saúde, ao lazer,à habitação digna.Isto é uma obrigação do Estado,cujo descumprimento deve gerar punições. Na verdade,o que mais fere o idoso é a exclusão,o desamparo de parentes e da sociedade.Ter qualidade de vida não é apenas ter saúde física e mental.É preciso estar de bem com sua própria consciência.Isto só ocorre quando se está de bem com seus familiares e com as pessoas ao seu redor.

A palavra chave quanto à qualidade de vida dos idosos seria o equilíbrio. Para os idosos atingirem este ponto, os deveres do Estado para com eles são cumpridos ao mesmo tempo em que são respeitados por sua família e pela sociedade, que os integra na comunidade, conforme aponta o Estatuto do Idoso ${ }^{53}$. Quando tudo isto estiver sendo cumprido, será esse o momento em que os idosos terão atingido uma verdadeira qualidade de vida.

Ocorre que não é isso que vemos nos dias atuais. Nenhum dos aspectos citados até aqui é respeitado. A característica do processo de envelhecimento no Brasil está no abandono dos idosos por todos os personagens aqui citados. O que caracteriza este grupo da população são as

\footnotetext{
${ }^{53}$ Artigo $3^{\circ}$ É obrigação da família, da comunidade, da sociedade e do Poder Público assegurar ao idoso, com absoluta prioridade, a efetivação do direito à vida, à saúde, à alimentação, à educação, à cultura, ao esporte, ao lazer, ao trabalho, à cidadania, à liberdade, à dignidade, ao respeito e à convivência familiar e comunitária.
} 
condições adversas por eles enfrentados, sejam nos aspectos físicos, biológicos, psicológicos ou sociais.

Quanto ao papel do Estado em relação aos cuidados com a terceira idade, vivenciamos o completo abandono. O Estado é incapaz de atingir por completo os direitos dos idosos previstos no texto constitucional. Ao não cumprir a previsão legal, o país deixa de cumprir os direitos consagrados para a população idosa. Este é apenas um aspecto do desrespeito aos idosos, que os impede de ter uma vida com qualidade. Poderíamos estender nossos olhos para a precária rede de saúde hospitalar do nosso país. Ou então abordarmos os inúmeros lares deste país onde os idosos daquele lar não conseguem ter uma rede de saneamento básico eficaz, o que agrava o quadro médico destes personagens, por causa das doenças surgidas pela falta de saneamento. Acontece que estes cenários, infelizmente, não são exclusividade dos idosos. Eles atingem a toda população brasileira. Isso mostra que o Estado é ineficiente para todos.

Ao analisarmos os dados estatísticos mais recentes ${ }^{54}$,podemos encontrar justificativas para o agravamento desta situação. Em virtude das dificuldades econômicas de sermos um país em eterno desenvolvimento, uma grande faixa da população economicamente ativa está desempregada. Com isso, podemos notar que uma parcela significativa da população idosa atua como o chefe da família, tendo os proventos da sua aposentadoria como a única fonte de sustento do lar. Na maioria das vezes, estes proventos são insuficientes, o que acaba obrigando o idoso a voltar ao mercado de trabalho,quando na verdade deveria estará gozando do merecido descanso,depois de tanto ter contribuído com a sociedade.

Quanto ao papel da família no cuidado para com os seus idosos, vemos uma mudança de comportamento quando comparada com décadas anteriores. A enlouquecedora dinâmica do mundo contemporâneo associada com a capitalização dos interesses pessoais faz com que as pessoas tenham seus valores um pouco deturpados. O individualismo que predomina nos

\footnotetext{
${ }^{54}$ IBGE - Pesquisa Nacional de Amostra de Domicílios-PNAD 2006
} 
objetivos pessoais acaba proporcionando a perda da compreensão do que é a família. Isto traz como conseqüência uma ausência absurda na educação dos filhos, cujas conseqüências seriam dignas de um outro trabalho, e o abandono dos familiares idosos.

Com isso, vemos cada vez mais idosos serem abandonados por suas famílias em casas de repouso, também conhecidas como asilos. A Função destas casas é de receber senhores e senhoras, cujas deficiências estariam supostamente impedindo que eles vivam integrados à família e à sociedade.

Ocorre que muitas dessas casas não têm a menor condição de estar recebendo esses idosos de forma digna, se transformando em verdadeiros depósitos de gente, em um triste cenário de indignidade e desrespeito aos valores da vida humana. Esta situação ofende por completo ao princípio da dignidade da pessoa humana, já tão citado aqui nesta obra. Esse abandono por parte dos parentes e amigos faz com que os idosos entrem em um processo de depressão profunda, o que acaba sendo um fator agravante para o quadro de doença que estes pacientes acabam trazendo.

Quanto ao papel da sociedade perante os idosos, vemos que as sociedades acaba se esquecendo daqueles que a ajudaram a ser construída. A integração com a sociedade em que vivem é considerada como um meio de obter qualidade de vida. Não deve ser permitida qualquer forma de tratamento que faça com que estes idosos sejam considerados seres fora da sociedade. Porém, o que vemos são idosos sendo desrespeitados. Seja através de agressões físicas ou morais feitas por membros da sociedade ou então por preconceito pela questão da idade, muitos idosos acabam sendo desrespeitados. Diversas pessoas que procuram emprego para sustentar o seu lar, mesmo após a aposentadoria, são recusadas unicamente por serem idosos. $\mathrm{O}$ argumento de que estas pessoas não teriam condições físicas para desempenhar certas atividades nada mais é do que preconceito, e que deve de alguma forma ser combatido. 
Como podemos perceber, estes deveres estão inseridos no ordenamento jurídico nacional ${ }^{55}$.Porém, o Estado, as famílias e a sociedade não cumprem a obrigação de proteger aos idosos. Somente quando lhes forem garantidos um amparo efetivo combinado com a sua integração à sociedade, é que a sua dignidade e o seu bem estar estarão garantindo uma efetiva qualidade de vida para os idosos.

${ }^{55}$ Artigo 230 da Constituição Federal de 1988 


\section{Capítulo 6: Os Idosos e a Legislação}

\section{1: A Constituição de 1988}

A Constituição da República Federativa do Brasil de 1988 mudou a estrutura do Direito Constitucional Brasileiro. Devido ao contexto histórico em que foi criada, no início do processo de redemocratização do Brasil após a Ditadura Militar, o texto constitucional traz uma preocupação muito grande com as questões ligadas a direitos individuais. A carta do povo é aquela que mais concede direitos à população. A grande expansão de direitos concedidos faz com que muitos destes não possam ser efetivamente cumpridos. Afinal, há muito mais direitos do que deveres no texto constitucional e para cumprir tudo o que é previsto, o Estado precisaria de muito mais recursos do que possui ${ }^{56}$.

Mesmo assim, é importante que o Estado olhe com atenção para esta camada da população, que tanto contribuiu para construção da sociedade que somos hoje. Cabe ao Poder Público atuar de forma efetiva para que essas dificuldades sejam reduzidas, e todos da sociedade possam se estabelecer sob as mesmas condições, respeitando assim a idéia do Princípio da Igualdade. Além deste princípio fundamental, a atuação do Estado para com os idosos marca a consagração do princípio da dignidade da pessoa humana.

A Constituição entende os idosos como sujeitos de direito. Isso faz com que sejam a eles estendidos um rol de direitos e princípios previstos no texto constitucional. Apesar de não estar previsto no rol do Artigo $6^{057}$ da Constituição, os direitos dos idosos podem ser entendidos como um direito

\footnotetext{
${ }^{56}$ Para cada direito concedido,é preciso previsão de receitas no orçamento.Afinal,existem despesas para cobrir por causa destes benefícios concedidos pelo texto constitucional.É o caso da previdência social,onde a concessão de pensão para aqueles trabalhadores rurais que nunca contribuíram com a Previdência,acaba por ser um dos fatores que elevam o rombo das contas do Estado.De outro modo,vale lembrar que cada real concedido pode ser entendido como investimento pois melhoram-se condições de vida,de saúde, de educação,precisando menos gastos por parte do Estado.Dai esta questão ser tão polemica.

57 Artigo $6^{\circ}$ : São direitos sociais a educação, a saúde, o trabalho, a moradia, o lazer, a segurança, a previdência social, a proteção à maternidade e à infância, a assistência aos desamparados, na forma desta Constituição.
} 
social. É obrigação de todos prestar assistência aos idosos de nosso país. Com estes direitos, são estendidos para estas pessoas, alguns dos princípios fundamentais previstos na carta do povo. A base para estes direitos está na consagração do Princípio da Dignidade da Pessoa Humana ${ }^{58}$.

Porém, a norma constitucional que destina direitos aos idosos pode ser classificada como uma norma de conceito aberto, que apenas determina, em caráter amplo, direitos subjetivos destinados aos personagens ali citados. Não há nenhuma determinação de como isto possa ser feito daí à necessidade deste artigo ser regulamentado. Não basta a mera previsão no texto constitucional para fazer com que os direitos dos idosos sejam realmente efetivados. Como nós sabemos, o Brasil tem uma característica peculiar, que faz que essas normas não produzam os resultados esperados para ela.

Como bem ensina o professor José Afonso da Silva ${ }^{59}$, as normas constitucionais podem ser classificadas quanto a sua eficácia, como normas de eficácia plena, de eficácia limitada e de eficácia contida. No primeiro caso, a aplicabilidade da norma constitucional é indireta, mediata e reduzida. Somente produzem efeitos quando da existência de norma posterior que tem como objetivo garantir a aplicabilidade da primeira norma. Já as normas de eficácia imediata são aquelas que podem ser aplicadas de imediato e desde já produzindo efeitos sem qualquer tipo de limitação.

No nosso entendimento, o Artigo 230 da Constituição Federal de 1988 pode ser considerado como uma norma de eficácia contida, mas de aplicabilidade imediata. Esta conclusão decorre da idéia de que o benefício da gratuidade dentro dos transportes coletivos tem como um dos fundamentos que justificam tal posição a idéia de que se deve respeitar o princípio fundamental da dignidade da pessoa humana. O exercício destes princípios não depende de normas reguladoras. Estas normas não existem

\footnotetext{
${ }^{58}$ Artigo $1^{\circ}$ IV da Constituição Federal de 1988

${ }^{59}$ Silva, José Afonso da. Curso de Direito Constitucional Positivo. 16 ${ }^{\mathrm{a}}$ ed. São Paulo: Malheiros, 1999.p.271.
} 
para conceder estes benefícios, e sim para regular a forma com a qual os mesmos serão concedidos.

O texto constitucional já traz embutido no seu corpo os direitos concedidos aos idosos. Resta uma autorização do texto constitucional para que o legislador possa criar leis que irão determinar a atuação do Estado para com esta parcela da população. A partir deste momento vieram atuações do Estado confirmando este sentido. É a partir da Política Nacional do Idoso $^{60}$ e do Estatuto do Idoso $^{61}$ que os caminhos para se garantir a eficácia dos direitos dos idosos vieram a ser traçados.

\section{2: Da Política Nacional do Idoso}

A lei 8.842/94, que criou a Política Nacional do Idoso, surgiu para traçar todas as linhas setoriais de atuação do Estado, para que este desenvolva atividades que venham a garantir a efetividade dos direitos fornecidos para os idosos. De acordo com a leitura do texto da lei, o objetivo primordial da Política Nacional do Idoso é de criar políticas para atuação do Estado a fim de assegurar o cumprimento dos direitos sociais do Idoso, cujo sentido foram reforçados e ampliados anos depois com a criação do Estatuto do Idoso. No artigo $3^{\circ}$ da lei 8.842, destaca-se a enumeração dos princípios que regem a Política Nacional do Idoso, onde sua leitura mostra claramente como, neste país, é vedada toda e qualquer manifestação de preconceito, no caso, contra os idosos. Estes Princípios reforçam também a soberania do princípio da dignidade da pessoa humana sobre qualquer situação ou o princípio do contraditório.

Art. $3^{\circ}$ A política nacional do idoso reger-se-á pelos seguintes princípios:

I - a família, a sociedade e o estado têm o dever de assegurar ao idoso todos os direitos da cidadania, garantindo sua participação na comunidade, defendendo sua dignidade, bem-estar e o direito à vida;

II - o processo de envelhecimento diz respeito à sociedade em geral, devendo ser objeto de conhecimento e informação para todos;

III - o idoso não deve sofrer discriminação de qualquer natureza;

\footnotetext{
${ }^{60}$ Lei $8.842 / 94$

${ }^{61}$ Lei $10.471 / 03$
} 
IV - o idoso deve ser o principal agente e o destinatário das transformações a serem efetivadas através desta política;

V - as diferenças econômicas, sociais, regionais e, particularmente, as contradições entre o meio rural e o urbano do Brasil deverão ser observadas pelos poderes públicos e pela sociedade em geral, na aplicação desta lei.

\subsection{1: Do Conselho Nacional do Idoso}

A primeira menção ao Conselho Nacional do Idoso em um texto normativo veio com a Lei 8.842/94 que previa nos artigos 11 a 18 à sua criação. Porém, estes artigos vieram a ser vetados pelo então Presidente da República, Senhor Itamar Franco. Uma nova menção a criação do Conselho foi feita através do Decreto 4.227 de 2002, que veio para realmente efetivar a sua criação. Além disso, este decreto dispõe sobre a criação, competência e composição do CNDI. Ocorre que em 17 de Junho de 2004, o decreto foi revogado pela edição do Decreto 5109, que com base na Lei 8.842/94(Política Nacional do Idoso) e na Lei 10.683 (Organização da Presidência da República e dos Ministérios), dispôs sobre novas competências, funções e atribuições do CNDI, que perdura até hoje.

Com a criação do Estatuto do Idoso, este Conselho passou a ter entre suas funções a necessidade de elaborar as diretrizes para a formulação e realização de atividades com base na Política Nacional do Idoso observando as linhas de ação, os princípios e as finalidades do Estatuto.

O Conselho Nacional do Idoso é um órgão ligado a Secretária Nacional de Direitos Humanos da Presidência da República. É um colegiado composto, de acordo com o artigo $3^{\circ}$ do Decreto, por 28 membros designados a seguir:

-1 representante da Secretaria Nacional de Direitos Humanos.

-1 representante da cada um dos seguintes Ministérios: Relações Exteriores, Trabalho e Emprego, Educação, Saúde, Cultura, Esporte, Justiça, Previdência Social, Turismo, das Cidades, Ciência e Tecnologia, Planejamento e do Desenvolvimento Social e Combate a Fome.

-14 membros de entidades da sociedade civil, que não tenham fins lucrativos, e atuem no campo da promoção e defesa dos direitos da pessoa 
idosa, e que sejam filiadas e organizadas em, pelo menos, cinco unidades da Federação, distribuídas em três regiões do País.

Dentre as principais atribuições do CNDI, destaca-se, a necessidade das decisões do Conselho servirem como sustentação para que as diretrizes apontadas pela Política Nacional do Idoso possam ser concretizadas, analisando a atuação da esfera governamental em nível federal, estadual, municipal e distrital, além da atuação dos Conselhos Regionais de Idosos destas respectivas esferas. Ao CNDI cabe dar sugestões de novos programas que ampliem a defesa dos direitos dos idosos, propondo sempre que necessárias mudanças na estrutura de atuação pública, para melhor atender os idosos. Cabe também ao CNDI, apoiar a promoção de campanhas educativas sobre os direitos do idoso, com a indicação das medidas a serem adotadas nos casos de atentados ou violação desses direitos.

\section{3: Estatuto do Idoso}

A constitucionalização dos direitos desta população trouxe perspectivas de um futuro melhor para este grupo. Porém, não basta conceder os direitos sem efetivá-los. Foi a partir daí que começou a pressão popular, apoiada pelas entidades de defesa dos direitos dos idosos, para que se fizesse algo para regular estes direitos para que os mesmo deixassem de ser uma mera previsão legal para se tornar uma realidade do dia a dia da terceira idade.

Neste momento surgiu a idéia de se criar um Estatuto que viesse para regular estes direitos além de definir medidas de proteção para os mesmos. Para tal, foi então apresentado o projeto de lei 3.561/97, de autoria do então Deputado Federal e hoje Senador, o gaúcho Paulo Paim (PT-RS). Trata-se de um parlamentar cujo histórico de atuação vem sendo voltada para ampliação e a proteção dos direitos das minorias, em especial aos idosos ${ }^{62}$.

\footnotetext{
${ }^{62} \mathrm{http}: / /$ www.senado.gov.br/paulopaim
} 
Durante o processo legislativo ${ }^{63}$, devido à relevância do tema, houve uma série de alterações no projeto original. Foram inúmeras emendas apresentadas por parlamentares ${ }^{64}$ do Congresso Nacional. Isso fez com que todo processo legislativo, incluindo a fase de audiências públicas, completasse sete anos, sendo um dos projetos que mais tempo levaram para ser aprovado.

Pois em $1^{\mathrm{o}}$ de Outubro de 2003 , o projeto de lei foi sancionado pelo Presidente da República Luiz Inácio Lula da Silva. Estava criado o Estatuto do Idoso. Não foi por acaso que a data foi a escolhida para a promulgação. Esta data é internacionalmente conhecida como o Dia Internacional dos Idosos. Em comemoração a criação do Estatuto, a partir de 2006, passou a representar também o Dia Nacional do Idoso no Brasil que até então era comemorado no dia 27 de Setembro.

A verdadeira função do Estatuto é fortalecer o controle do Poder Público em relação ao tratamento com as pessoas idosas. Através da consagração da idéia de dignidade, o Estatuto do Idoso busca dar o respeito merecido por estas pessoas. Ao transformar a educação do cidadão, quanto aos idosos, estaremos garantindo um idoso com participação ativa, um cidadão efetivo da sociedade.

A criação do Estatuto do Idoso foi uma revolução no ordenamento jurídico brasileiro, referente aos direitos dos idosos. Além de regular os direitos já previstos no texto constitucional, consagrando os princípios da Política Nacional do Idoso, o Estatuto trouxe uma série de novidades que mudaram a estrutura da sociedade quanto aos direitos dos idosos, sendo uma resposta do Estado e da sociedade para que as necessidades destas pessoas possam ser efetivamente sanadas.

\footnotetext{
${ }^{63}$ Moraes, Alexandre de. Direito Constitucional. 22a . ed.Atlas,2007.p.630-649

${ }^{64}$ existem 3 tipos de Emendas Parlamentares.Quando eliminam uma parte da proposta original,elas são classificadas como Emendas Supressivas.Quando acrescentam algo ao projeto inicial,são Emendas Aditivas.Quando alteram o texto original,elas são Emendas Modificativas,conforme o artigo 118 do Regimento Interno da Câmara dos Deputados.
} 
Além de reafirmar aos idosos a proteção dos seus direitos básicos de cidadão, o Estatuto trabalha com a noção de discriminação positiva, concedendo uma série de privilégios e preferências no tratamento aos idosos. Como todos percebem, as pessoas da terceira idade são as mais fragilizadas dentro de nossa sociedade, precisando de um tratamento diferenciado para que venham a se igualar aos demais membros da comunidade.

$\mathrm{Na}$ área criminal, a lei $10.741 / 2003$ instituiu penas mais severas contra aqueles que pratiquem ato contra os idosos, ou que violem alguns dos seus direitos. Desta forma, o Estado tenta eliminar uma questão que vinha impedindo uma efetivação destes direitos, que é a impunidade para quem pratique algum tipo de ato contra os idosos.O Estado amplia a rede de proteção das pessoas da terceira idade, desfavorecidas perante as pessoas de outras faixas etárias, de modo a efetivar a garantia do respeito a dignidade da pessoa,também consagrado no Estatuto do Idoso ${ }^{65}$.

Seguindo a mesma inspiração de respeito a este princípio, o texto da lei 10.741/03 traz uma série de garantias e direitos fundamentais para os idosos ligados a área de saúde, educação, esporte, lazer, trabalho. Todas elas reafirmam a preocupação do Estado em ampliar a rede de proteção para os idosos, garantindo condições de vida digna para este grupo social, que necessita cada vez mais da proteção do Estado, a partir do momento que é o grupo etário que mais cresce. Dentre os pontos principais destacam-se a vedação a qualquer tipo de preconceito de idade para o idoso que está a procura de trabalho, atendimento preferencial na fila do SUS e a concessão de descontos de ingressos para os idosos em atividades culturais e eventos esportivos.

A grande questão que envolve a concessão destes benefícios está na aplicabilidade de muitos destes dispositivos. Quando se estende uma série de oportunidades e direitos a qualquer grupo social, encontramos sempre

\footnotetext{
${ }^{65}$ Art. 10. É obrigação do Estado e da sociedade, assegurar à pessoa idosa a liberdade, o respeito e a dignidade, como pessoa humana e sujeito de direitos civis, políticos, individuais e sociais, garantidos na Constituição e nas leis.
} 
um grupo dissidente, formado quase sempre pelas pessoas que sofrem a intervenção do Estado nestes casos, que irá questionar estas benesses. Estes grupos irão sempre resistir a qualquer tipo de mudança que possa ameaçar seus lucros ou supostamente contrariar algum direito seu. Cabe ao Poder Público atuar da melhor forma no Poder Judiciário para que sejam consideradas legais tais atuações do Estado.

\section{4: Aplicação Prática dos Direitos dos Idosos}

Este tópico visa traçar os caminhos que o Estado utiliza para garantir que todos os idosos tenham condições dignas para viver. São vários os mecanismos de atuação do Estado no cumprimento destes objetivos. É obrigação do Estado atuar para garantir a efetivação destes direitos,orientando-se sempre pelas diretrizes estabelecida na sua Política Nacional de $\operatorname{Idosos}^{66}$ Dentre estes mecanismos de atuação destaca-se a rede de assistência social, garantia constitucional que visa conceder condições dignas para os idosos. Escolhemos o Sistema Previdenciário e o Sistema Único de Saúde como exemplos de atuação do Estado para com os idosos, e sobre este sistema passaremos a falar a partir de agora.

O Sistema Previdenciário Brasileiro está previsto no texto constitucional do artigo 201 da Constituição Federal de $1988^{67}$, cujo texto foi alterado pela Emenda Constitucional $\mathrm{N}^{\mathrm{o}} 20 / 98$, que veio para modificar o sistema de previdência social e estabelecer algumas regras para a efetiva transição da condição de pessoa economicamente ativa para a aposentadoria.

Desta forma, durante todos os anos de seu trabalho, o contribuinte tem um desconto em sua folha salarial para a chamada contribuição previdenciária, que irá formar as receitas que garantirão o pagamento

\footnotetext{
${ }^{66}$ Artigo $4^{\circ}$ da Lei $8.842 / 94$

${ }^{67}$ Artigo 201: a previdência social será organizada na forma de regime geral, sendo obrigatório se filiar ao regime previdenciário, adotando o regime contributivo.
} 
quando de sua aposentadoria. Para o homem, são necessários 65 anos de idade e 35 de contribuição enquanto para as mulheres tem 60 anos de idade e 30 de contribuição. Recentemente, houve uma pequena reforma previdenciária, que dentre outras novidades introduziu a taxação para os servidores inativos, numa matéria controversa, e que poderá ser analisada mais profundamente em outro trabalho.

Esse sistema atinge a todos os idosos brasileiros, que, quando se aposentam por tempo de serviço ou invalidez, têm direito a aposentadoria. Neste ponto, reside o maior problema deste sistema, fonte principal para seu déficit financeiro, uma vez que todos, inclusive aqueles que não recolheram a contribuição previdenciária tem direito a receber pelo menos um salário mínimo. Percebemos uma dualidade na atuação do Estado neste momento. Enquanto que para algumas situações o Estado é extremamente patrimonialista, em outras, como no caso desta regra de aposentadoria, o Estado é nitidamente assistencialista. É por causa desta postura que as conta do sistema previdenciário brasileiro tem um enorme déficit. Tal prejuízo acaba pondo em risco as aposentadorias já existentes e contribuindo para que os valores pagos sejam tão baixos.

O Sistema Único de Saúde (SUS) foi criado em 1988, como uma novidade introduzida pelo texto da nova Constituição ${ }^{68}$. O SUS Foi criado através da Lei 8.080/90 e regulamentado pela Lei 8.142/90. O objetivo de sua criação foi de descentralizar a rede de atendimento de saúde no Brasil. Por sermos um país de dimensões continentais, cada região tem suas especificidades.

Assim, nada melhor do que um sistema descentralizado para melhor atingir os objetivos pretendidos de acabar com as desigualdades. A saúde é um dever do Estado e um direito de todos os cidadãos brasileiros. Para isso, o SUS determina o atendimento a todo público, uma vez que ninguém é obrigado a desembolsar um centavo por uma consulta médica num dos

\footnotetext{
${ }^{68}$ Art. 196. A saúde é direito de todos e dever do Estado, garantido mediante políticas sociais e econômicas que visem à redução do risco de doença e de outros agravos e ao acesso universal e igualitário às ações e serviços para sua promoção, proteção e recuperação.
} 
conveniados a rede SUS de atendimento. Quem paga esta conta é o Estado, em todas as suas esferas, cujos recursos provem de impostos e contribuições sociais, como a tão polêmica Contribuição Provisória sobre Movimentação Financeira (CPMF), cujos recursos devem ter esta destinação.

Do Sistema Único de Saúde fazem parte os centros e postos de saúde, hospitais públicos e universitários, hemocentros, fundações e institutos de pesquisa. Empresas particulares podem participar do SUS, desde que em caráter complementar. Todos os cidadãos têm direito a consultas, exames, internações e tratamentos junto àqueles vinculados ao SUS, sejam eles públicos ou privados, quando contratadas pelo gestor público de saúde em caráter suplementar.

Através deste Sistema de Saúde, deveríamos ter atendimento de qualidade. Ocorre que a rede está sucateada, fruto da incompetência administrativa dos gestores brasileiros. Hoje em dia, o valor remunerado aos hospitais por consultas do SUS são muito baixo. Isto reflete na qualidade de atendimento de toda sociedade, agravada a situação na parcela dos idosos, cujo estado de saúde já limitado, é agravado por causa do desleixo do Estado.

Exitem ainda as ações afirmativas desempenhadas pelo Estado a fim de conceder aos idosos uma vida com melhores condições, de forma a lhes garantir a extensão dos princípios fundamentais de direito garantido pelo texto constitucional. Dentre estas possibilidades de ação afirmativa, a que vem levantando maiores polêmicas a cerca de sua validade jurídica é a concessão do benefício da gratuidade para os idosos nos transportes coletivos. 


\section{Capítulo 7: A Gratuidade e o Transporte Coletivo}

\section{1: A Previsão Constitucional}

A Constituição da República Federativa do Brasil de 1988 traz um capítulo específico sobre os direitos da família, das crianças, dos adolescentes e dos idosos. Quanto a este último grupo, tema de nosso trabalho, a Constituição estabelece de maneira geral a necessidade de se prestar uma atenção maior a este grupo social. Os Idosos são pessoas de direito, e por isto já são protegidos por uma série de direitos fundamentais previstos para todos na sociedade.

Talvez seja por isto que o texto constitucional,quando se refere aos direitos dos idosos, aborda a questão de maneira geral. Há apenas uma determinação legal que obriga o Estado, a sociedade e as famílias a atuarem em conjunto para garantir condições de vida digna para os idosos com base no respeito ao princípio fundamental da dignidade da pessoa humana, sem permitir que exista qualquer tipo de discriminação devido a condição de idoso.

Todos os outros direitos dos idosos derivam desta obrigação do Estado fazer suprir as necessidades dos idosos. Isto é feito através de ações afirmativas, cujo objetivo é garantir aos idosos a extensão de seus direitos, de forma a atingir os ideais planejados através dos princípios fundamentais. Os direitos que derivam do preceito da dignidade da pessoa humana, acabam sendo especificados através de normas que regulamentam a aplicação do texto constitucional.

Porém, podemos perceber que o constituinte preferiu especificar um direito em especial dentre daqueles concedidos abstratamente aos idosos. Trata-se da obrigatoriedade do Estado conceder gratuidade para os idosos nas passagens de transporte coletivo, uma previsão expressa no artigo 230 § $2^{\circ}$ da Constituição Federal de $1988^{69}$.

\footnotetext{
${ }^{69}$ Art.230 $\S 2^{\circ}$ : Aos maiores de sessenta e cinco anos é garantida a gratuidade dos transportes coletivos urbanos.
} 
Esta previsão vem inspirada nas idéias de defesa do direito de livre locomoção dentro do território nacional ${ }^{70} \mathrm{e}$ da necessidade de se manter os idosos integrados na sociedade. Sabemos que as limitações físicas dos idosos associada as dificuldades financeiras de suas pequenas aposentadorias, acabam por impedir que os idosos tenham uma participação mais útil na vida da sociedade,o que acaba muita das vezes resultando em idosos entrevados na cama de um hospital ou da sua própria casa.

Ao decidir que a gratuidade nos transportes públicos coletivos seria o único direito dos idosos citados especificamente dentro do texto constitucional, o legislador quis realçar a idéia do Estado proteger a locomoção destes indivíduos, com base no respeito ao direito de ir e vir de cada cidadão. Nestes casos, o Poder Público deve atuar para proteger a aplicação deste direito, especialmente no caso dos idosos, cuja atenção deve ser maior, por se tratar de um grupo socialmente mais fragilizado que os demais e que merece uma proteção maior que os outros grupos que compõe nossa sociedade.

Porém, como já vimos anteriormente, o artigo 230 da Constituição Federal e seus parágrafos são de difícil classificação dentro das opções desenvolvidas por José Afonso da Silva. Optamos por classificar estas normas como de eficácia contida, mas de aplicabilidade imediata, reconhecendo a possibilidade de outras classificações dentre as descritas por José Afonso da Silva, tão grande é a polêmica sobre esta questão. Isto ocorre pelo fato de serem direitos obrigatórios, sem a necessidade de lei para concedê-los. Esta espécie normativa só seria útil para garantir que os efeitos se estendessem a todos. Sendo assim, para se tornar efetiva, essa norma precisa da elaboração de outras normas que venham a regular estes direitos subjetivos.

Essas normas são o Estatuto do Idoso e o Decreto 5.934/06. O objetivo do Estatuto é identificar as condições necessárias para se ter direito 
ao benefício da gratuidade. Já o Decreto 5.934/06 foi elaborado para criar os mecanismos para que a atuação do Estado em favor dos idosos deixe de ser uma previsão legal e passe a ser de fato uma ação concreta do Estado.

\section{2: A Regulamentação da Gratuidade nos Transportes Coletivos.}

O Estatuto do Idoso veio para estabelecer os critérios que seriam utilizados para identificar quem seriam os beneficiados de tal gratuidade. Os critérios para a concessão da gratuidade vieram especificados nos artigos 39 a 42 da Lei 10.741/03, e merecem passar por uma criteriosa análise, fruto de inúmeras contradições que apresentam, e sobre as quais passaremos a discutir.

O conceito internacional sobre quem possa ser classificado como um idoso determina que uma pessoa deva ser assim considerada a partir do momento em que completa 60 anos de idade. Este conceito também está consagrado dentro do ordenamento jurídico nacional, através do texto do artigo $1^{\circ}$ do Estatuto do Idoso. Porém, curiosamente, tanto o texto constitucional ${ }^{71}$ como o artigo 39 do Estatuto do Idoso restringem a concessão de gratuidade nos transportes coletivos para os idosos que tenham mais do que 65 anos. Com isto podemos entender que o legislador quis restringir os idosos que teriam direito a este benefício, o que iria em contrário com o próprio conceito expresso no Estatuto do Idoso ${ }^{72}$.

"Art. 39. Aos maiores de 65 (sessenta e cinco) anos fica assegurada à gratuidade dos transportes coletivos públicos urbanos e semi-urbanos, exceto nos serviços seletivos e especiais, quando prestados paralelamente aos serviços regulares."

Ao estabelecer esta gratuidade, buscou-se dar o devido amparo aos idosos, reforçando a idéia de integração a sociedade, facilitando a locomoção dos mesmos, já tão dificultada nesta época da vida. Essa

\footnotetext{
${ }^{71}$ Artigo $230 \S 2^{\circ}$ da Constituição Federal de 1988

${ }^{72}$ Artigo $1^{\circ}$ do Estatuto do Idoso
} 
dificuldade acaba servindo como um dos fatores impeditivos para tal integração. Ocorre que as necessidades dos idosos maiores de 65 anos são as mesmas apresentadas por parte daqueles que tem entre 60 e 65 anos. Entendemos que a não concessão da gratuidade para essa parcela da população idosa seria considerada uma espécie de discriminação por parte do legislador para com os idosos.Isto é vedado pelos princípios que compõe toda Política Nacional de Idosos ${ }^{73}$ e o próprio Estatuto do Idoso.

Inúmeros projetos de $\mathrm{ei}^{74}$ foram apresentados para alterar o texto constitucional e ampliar este direito a todos os idosos. Esses projetos foram rejeitados sem análise de seu mérito,visto que não é possível alterar o texto da Constituição por meio de lei ordinária ${ }^{75}$.Tal problema passa a ser solucionado a partir do momento em que o legislador federal transfere para o legislador local a competência para lidar com a questão da gratuidade para os idosos que tenham entrem 60 e 65 anos de idade.

Com este exemplo, fica clara uma outra característica marcante envolvendo a questão da gratuidade. As determinações assumidas pelo texto do Estatuto do Idoso são de estabelecer uma série de regras, regulamentadas pelo Decreto 5.934/06, que acabam tendo apenas um caráter geral sobre a matéria, precisando de outras normas que especifiquem os caminhos e as formas de sua aplicação, de acordo com as características de cada localidade. O próprio Estatuto do Idoso faz uso deste princípio, ao delegar para a legislação local a possibilidade de estender a gratuidade nos transportes coletivos para os idosos compreendidos na faixa entre 60 e 65 anos.

“Art.39 § 3o No caso das pessoas compreendidas na faixa etária entre 60 (sessenta) e 65 (sessenta e cinco) anos, ficará a critério da legislação local dispor sobre as condições para exercício da gratuidade nos meios de transporte previstos no caput deste artigo"

\footnotetext{
${ }^{73}$ Art. $3^{\circ}$ III da Lei 8.842/94

${ }^{74}$ Projeto de Lei $5.132 / 05$

${ }^{75} \mathrm{O}$ texto constitucional só pode ser alterado mediante Emenda Constitucional,através de votação de dois turnos em cada uma das casas legislativas,aprovados por $2 / 3$ das respectivas casas, ou seja,pelo voto de 54 senadores e 242 deputados
} 
O transporte coletivo urbano, conforme o artigo 39 do Estatuto dos Idosos pode ser classificado como municipal (dentro do município), intermunicipal (entre municípios distintos dentro de um Estado) e interestadual (entre Estados distintos). Há um quarto tipo de transporte que é o internacional ,que começa em um dos Estados do Brasil e ultrapassa a fronteira de um país vizinho.

A competência para legislar sobre transporte é privativa da União ${ }^{76}$.Porém, isto não impede que os Municípios legislem sobre tal matéria que envolva o transporte coletivo interno. Através do inciso IV do artigo $30 \mathrm{da} \mathrm{CF}$, os Municípios ganham competência para organizar os serviços públicos de interesse local, inclusive os de transporte. A legislação municipal deve ter um caráter suplementar em relação à legislação federal, não entrando em conflito com as normas gerais elaboradas pela União ${ }^{77}$.

A saída encontrada pelo Artigo $39 \S 3^{\circ}$ acaba sendo questionada. Afirmam que a simples delegação aos Municípios da competência para determinar ou não a extensão desta gratuidade, não explicaria a suposta falha do texto constitucional de excluir os que têm entre 60 e 65 anos do benefício da gratuidade. Os críticos afirmam se tratar de um claro ataque ao princípio constitucional da igualdade e ao princípio que veda qualquer tipo de discriminação aos idosos, posição esta que concordamos em parte.

Respeitando a idéia de suplementariedade da legislação municipal perante a legislação federal, que permite a legislação local criar suas próprias condições próprias, o Artigo 40 do Estatuto do Idoso vem para estabelecer a forma em que será concedida a gratuidade para os idosos nos transportes coletivos interestaduais. Através deste dispositivo, o legislador obriga as empresas de transporte a disponibilizarem dois assentos para os idosos beneficiados com a gratuidade. Cumprindo a obrigação de garantir melhores condições para todos os idosos, o legislador obriga ainda a concessão de $50 \%$ de desconto do preço da passagem quando o número de

\footnotetext{
${ }^{76}$ Artigo 22, XI da Constituição Federal de 1988.

${ }^{77}$ Artigo 30, II da Constituição Federal de 1988.
} 
idosos utilizando daquele veículo de transporte coletivo ultrapassar o limite de assentos reservados para tal benefício.

O legislador restringe aqueles que serão beneficiados pela gratuidade e pelo desconto no preço da passagem. Somente os idosos que têm renda igual ou inferior a 2 salários mínimos têm direito a tais benefícios.Quanto mais pobre for o idoso,mais efeito positivo terá em sua vida a chance de poder se locomover dentro da sociedade sem ter que arcar com nenhum custo.O critério de limite de renda escolhido pelo legislador não é o mais correto,como vermos mais a frente nesta obra.Mesmo assim,é escolhido como parâmetro para concessão do regime de gratuidade.

O Decreto 5.934/06 veio para estabelecer as regras para a disponibilização do benefício da gratuidade.Este decreto traz os procedimentos que os idosos devem realizar para efetivar o seu direito a gratuidade.Aqueles idosos que desejam obter os benefícios da gratuidade nos transportes coletivos interestaduais,sejam eles rodoviários,ferroviários ou aquaviários,devem solicitar uma espécie de bilhete único específico para o idoso,conforme a determinação do Artigo $3^{\circ} \S 2^{\circ}$ do Decreto 5.934/06.Esse bilhete deve ser requisitado com antecedência mínima de 3 horas do embarque,respeitando o princípio da não Surpresa para as empresas de transporte coletivo.A mesma regra de antecedência também vale para o bilhete com desconto de $50 \%$, conforme regra do artigo $4^{\circ}$ do presente decreto $^{78}$

O mesmo decreto ainda determina que, no momento do embarque, o idoso deve passar por um processo de fiscalização que irá determinar se ele realmente tem o direito à gratuidade da passagem. Para tanto deverá apresentar o documento de identidade na hora de fazer uso da passagem. Além disso, deve apresentar comprovante de renda que prove que o mesmo

\footnotetext{
${ }^{78} \mathrm{I}$ - para viagens com distância até $500 \mathrm{~km}$, com, no máximo, seis horas de antecedência;

II - para viagens com distância acima de $500 \mathrm{~km}$, com, no máximo, doze horas de antecedência.
} 
atende o requisito de ter renda inferior a 2 salários mínimos. Tal disposição está prevista no artigo $6^{\circ}$ do Decreto 5.934/06.

Art. 6: No ato da solicitação do "Bilhete de Viagem do Idoso" ou do desconto do valor da passagem, $o$ interessado deverá apresentar documento pessoal que faça prova de sua idade e da renda igual ou inferior a dois salários-mínimos. $\S 1^{\circ}$ : A prova de idade do idoso far-se-á mediante apresentação do original de qualquer documento pessoal de identidade, com fé pública, que contenha foto. $\S 2^{\circ}$ : A comprovação de renda será feita mediante a apresentação de um dos seguintes documentos:

I - Carteira de Trabalho e Previdência Social com anotações atualizadas;

II - contracheque de pagamento ou documento expedido pelo empregador;

III - carnê de contribuição para o Instituto Nacional do Seguro Social - INSS;

IV - extrato de pagamento de benefício ou declaração fornecida pelo INSS ou outro regime de previdência social público ou privado; $e$

V - documento ou carteira emitida pelas Secretarias Estaduais ou Municipais de Assistência Social ou congêneres.

Mesmo após estabelecidos todas as regras e procedimentos necessários para que o idoso possa exercer o seu direito a um transporte público gratuito,muitas vezes isso acaba não acontecendo.Algumas empresas de transporte coletivo não cumprem as determinações e impedem,através de medidas arbitrárias,que os idosos façam uso destes direitos. Por isto, o Estado precisa melhorar a questão da fiscalização das empresas de transporte de forma a evitar qualquer tipo de abuso para com os idosos. É direito do idoso exigir o cumprimento das regras previstas no Estatuto do Idoso.As empresas não podem em nenhum momento cometer qualquer tipo de abuso contra estas pessoas, que estão ali para lutar pelos seus direito.A grande luta destas empresas deve ser nos tribunais, para provar a inconstitucionalidade do benefício.

\section{3: A Questão da Constitucionalidade.}

Quando o Estado estabelece um benefício que se restringe apenas a uma parcela da população, essa atuação do Poder Público acaba sendo questionada. É assim com os programas sociais de qualquer governo, que buscam através da ação do Estado reduzir problemas como o desemprego de uma parte da população. O mesmo ocorre com as ações afirmativas, que 
são a atuação do Estado que, através de um tratamento diferenciado, diminuir a desigualdade social em um país tão desigual como o nosso.

Toda contrariedade em relação a esse tipo de atuação do Estado decorre de uma visão mesquinha da parte mais abastada da sociedade em relação aos problemas de nosso país. Todos cobram do Estado atitudes que minimizem ou resolvam estes problemas. Esta postura crítica não se repete quando para resolver este tipo de problema, a atuação do Estado incide reflexamente sobre o patrimônio, sobre a vida, sobre a atuação dentro da sociedade. São poucos que aceitam a idéia de que para resolver um problema, o Poder Público tenha que "esticar a corda" com a qual controla a sociedade, e atingir por reflexo aqueles que já tem boas condições e não precisam da atuação do Estado.

É fundamentado neste tipo de pensamento, em que não há muito espaço para a idéia de Responsabilidade Social, que acabam surgindo muitos dos questionamentos sobre a validade do Poder Público conceder gratuidade ou desconto para que os idosos façam uso do transporte público coletivo.

De um lado vemos os donos de empresas de transporte coletivo questionarem em pleno Supremo Tribunal Federal a constitucionalidade dos dispositivos legais que determinam tais benefícios, especialmente no que se refere ao artigo 39 do texto do Estatuto do Idoso, já transcrito aqui nesta obra. Do outro lado, vemos idosos buscando na justiça, o direito de fazer valer os seus direitos, muitas vezes denegados por parte destas empresas.

Neste questionamento sobre a constitucionalidade ou não do dispositivo do Estatuto do Idoso que disciplina a concessão do benefício da gratuidade nas passagens em transportes coletivos, inúmeros argumentos são levantados por ambas as partes. Selecionamos alguns destes argumentos, sobre os quais faremos uma análise detalhada a fim de chegarmos a nossa conclusão sobre este embate jurídico.

Uma parte do empresariado do setor de transporte coletivo alega que o texto do Artigo 39 do Estatuto do Idoso, apesar de suas boas intenções, 
vem a ser atacado pelo vício de inconstitucionalidade, pois claramente ofende ao princípio constitucional da igualdade. Alegam que o Poder Público, ao conceder aos idosos o benefício da gratuidade, estaria cometendo um ato discriminatório para com todo o restante da sociedade.

Afirmam, ainda, que o Estado tenta suprir as necessidades de uma parcela da população, ao garantir a locomoção destas pessoas que, devido a falta de dinheiro, deixam de utilizar os meios de transporte público e acabam por se isolar da sociedade. Ocorre que, numa sociedade onde milhares de pessoas são obrigadas a viver desempregadas ou com um salário mínimo que mal dá para se alimentar, não são apenas os idosos que precisavam da mão do Estado, e que por isto o benefício concedido aos idosos estaria ferindo o princípio da igualdade, devido a discriminante da idade.

A mesma situação ocorreria entre os próprios idosos. Não haveria motivos para justificar a diferença de tratamento entre os dois tipos de idosos, um que tenha mais de 65 anos e outro que tenha 60 anos, quando ambos recebam o limite de dois salários mínimos, previstos no Estatuto do Idoso. Segundo o conceito já definido nesta obra, ambos são pessoas classificadas como idosos dentro do preceito internacional consagrado no Estatuto do Idoso ${ }^{79}$ e por isso seriam dignos da consagração do benefício, já que as necessidades financeiras de ambos são as mesmas.

Além disso, ainda haveria a questão da renda. Os empresários questionam o fato de não haver diferenças entre as necessidades apresentadas por aqueles idosos com mais de 65 anos que recebem dois salários mínimos e os que recebem três salários mínimos, por exemplo. Assim, na visão destes empresários, estaria mais uma vez configurado o desrespeito ao princípio da igualdade por causa da discriminante de renda estabelecido. Devido a este desrespeito por parte do legislador, a concessão desta gratuidade deveria ser taxada como inconstitucional.

${ }^{79}$ Artigo $1^{\circ}$ da Lei $10.741 / 03$ 
Numa visão diametralmente oposta, uma outra parcela do empresariado do setor de transporte coletivo não entende como inconstitucional a gratuidade concedida para os idosos. Para os empresários, não há neste caso desrespeito ao princípio da igualdade. Trata-se de um direito social, que deve ser garantido aos idosos por meio da atuação do Estado. Eles não entendem existir qualquer tipo de desrespeito ao princípio da Igualdade.

Para estes empresários, o vício de inconstitucionalidade do Artigo 39 do Estatuto do Idoso estaria ligado ao fato da lei não ter previsto como o Estado iria arcar com os custos da concessão deste benefício. Argumentam que, na forma idealizada pelo legislador, o Poder Público resolveu apenas conceder este tipo de benefício sem estabelecer qualquer previsão orçamentária sobre estes custos. Argumentam, portanto que a concessão da gratuidade nos transportes coletivos deve ser submetida a idéia da reserva do possível,pois a prestação positiva prestada indiretamente pelo Estado seria extremamente onerosa a quem realmente efetiva tal benefício.

O serviço de transporte coletivo é organizado através do regime de concessão de serviço público ${ }^{80}$. Neste regime, as linhas são distribuídas através de um processo licitatório que normalmente é feito através da modalidade de concorrência, conforme a lei $8.666 / 96^{81}$. Então, entre as empresas vencedoras do processo licitatório e a Administração Pública é feito um contrato de concessão, onde são estabelecidas as normas que regerão o cumprimento do contrato ${ }^{82}$. Como não houve nenhuma previsão legal que determinasse algum tipo de compensação pela concessão da gratuidade, as despesas com este benefício acabam sendo transferidas diretamente, o que é a questão discutida.

\footnotetext{
${ }^{80}$ Artigo 175 da Constituição Federal de 1988

${ }^{81}$ Art. 22. São modalidades de licitação: I - concorrência;

${ }^{82}$ Alguns exemplos de normas que regem o cumprimento de contratos estão na previsão sobre reajuste de tarifas, tempo de duração da concessão, regras de rescisão do contrato, e clausulas de ajuste do equilíbrio econômico-financeiro dos contratos.
} 
Os empresários do ramo de transporte coletivo alegam que a concessão deste benefício estaria onerando excessivamente esses contratos, quebrando com o equilíbrio econômico financeiro dos contratos ${ }^{83}$. O que seria expressamente vedado nos princípios do contrato administrativo e no código civil ${ }^{84}$. Desta forma, por meio das associações representativas da atividade, as empresas de transporte ${ }^{85}$ buscam a declaração da inconstitucionalidade do artigo 39 do Estatuto do Idoso por meio de Ação Direta de Inconstitucionalidade.

Quanto ao primeiro argumento citado, entendemos não haver de nenhuma forma ofensa ao princípio da igualdade. A idéia de que o Estado estaria discriminando os demais indivíduos da sociedade não pode ser levantada como justificativa para se decidir pela inconstitucionalidade da concessão do benefício da gratuidade, na forma determinada pelo Estatuto do Idoso.

O texto constitucional veda qualquer tipo de discriminação no tratamento das pessoas. Porém, não podemos entender que o fato de se conceder a gratuidade apenas para os idosos seja um ato discriminatório com os demais indivíduos da sociedade. Afinal, o que é vedado pela Constituição Federal são as discriminações voltadas para a perseguição, com o intuito efetivo de prejudicar alguém diretamente,seja através de um tratamento diferenciado e preconceituoso,seja a omissão na atuação do Estado, mas que o único objetivo seja causar prejuízos a alguém.

No caso em questão, realmente vemos o Estado atuar em favor exclusivamente dos idosos. Também conhecida como discriminação positiva, trata-se de um tratamento diferenciado que busca diminuir a desigualdade pré-existente, que deixa os idosos de imediato, em situação desfavorecida perante os demais membros da sociedade. Devemos analisar que ao atuar em benefício exclusivo dos idosos, o Estado na verdade, está beneficiando toda a sociedade, pois está atuando para acabar com o vão que

\footnotetext{
${ }^{83}$ Artigo 37 XXI da Constituição Federal de 1988

${ }^{84}$ Artigo 478 do Código Civil de 2002

${ }^{85}$ Artigo 103 IX da Constituição Federal de 1988
} 
separa os idosos dos demais componentes da comunidade. Ao observarmos o perfil da sociedade do nosso país, podemos perceber que os idosos formam um dos grupos sociais mais desfavorecidos. Muitas destas pessoas vivem em situação precária, abandonadas pelas famílias, sobrevivendo com o pouco dinheiro das aposentadorias. Por falta de recursos, muitos idosos não se utilizam do transporte coletivo para visitar parentes, procurar hospitais, e acabam isolados dentro da sociedade.

Sendo assim, justifica-se a necessidade do Estado ter uma presença constante dentro da sociedade de forma a estabelecer uma série de políticas e intervenções que consiga fazer com que os idosos tenham uma vida digna. A concessão da gratuidade nos transporte coletivo acaba sendo uma destas formas de atuação do Estado. Através dela, o Poder Público garante aos idosos o direito fundamental da liberdade de locomoção, mantendo estas pessoas integradas a comunidade. Por isto, não há qualquer ofensa ao Princípio da Igualdade, por parte do legislador, ao conceder este benefício.

A mesma linha de raciocínio serve para justificar o fato de o legislador conceder a gratuidade apenas para os idosos com mais de 65 anos. Ao abrir mão de sua competência para determinar que este benefício concedido para todos os idosos, o legislador entendeu que cada região tem suas especificidades e por se tratar de algo oneroso as empresas e aos cofres públicos, caberia à legislação local determinar o quanto alcançaria a concessão deste benefício, desde que o mesmo fosse garantido.

Como podemos perceber, há um confronto entre princípios constitucionais. De um lado há a proteção a dignidade da pessoa humana. Do outro lado há uma suposta ofensa ao princípio da igualdade. Acreditamos que neste conflito de princípios, seguindo a teoria dos pesos, já citada nesta obra, deva prevalecer a importância do princípio da dignidade da pessoa, cuja importância é maior quando em conflito com o princípio da igualdade. A saída para este conflito de princípios está consagrada na possibilidade de tratamentos diferenciado para resolver situações de desigualdade,onde uma das justificativas é garantir melhores 
condições para quem até então se encontrava em inferioridade. É neste cenário que aparece na questão da gratuidade nos transportes coletivos. É o Estado garantindo o direito de ir e vir para um grupo que não tem condições de garantir sozinho,como outros membros da sociedade, o cumprimento deste seu direito.

O outro argumento levantado pelos donos de empresas de transporte também não pode ser considerado como justificativa para questionar a constitucionalidade do artigo 39 do Estatuto do Idoso. Não se pode alegar que a ausência de previsão legal sobre quem irá arcar com as despesas extras decorrentes do benefício concedido, seja um fundamento válido para não permitir algo que traga tanta ajuda para uma parcela tão necessitada.

Primeiramente, devemos entender que as empresas só exploram aquelas linhas de transporte devido ao contrato de concessão do serviço público estabelecido pelo Estado. É para ele que estas empresas devem obediência quanto as condições e regras estabelecidas, mesmo quando esta atuação reflete de alguma forma nos contratos assinados com o Poder Público

A gratuidade concedida para os idosos faz parte de uma atuação discricionária do Poder Público, cujos reflexos nos contratos exercidos com a administração pública não podem servir de argumento para suspender tal benefício. Se estas empresas alegam quebra do equilíbrio econômico financeiro do contrato, as mesmas devem buscar junto ao Estado concedente, algum tipo de mudança que venha a corrigir este equilíbrio financeiro, desde que não transfira a conta, através do aumento de tarifas, para o resto da população que utiliza destes serviços. Tal ato anularia os benefícios trazidos pela gratuidade.

Devemos entender, também, que como prestadoras de serviços públicos, estas empresas são detentoras de Responsabilidade Social. Apesar de serem empresas voltadas para a lucratividade de suas atividades, as mesmas estão sendo desempenhadas através de um serviço público, a elas 
concedidas por delegação do Estado. Não se trata apenas de uma atividade comercial. Deve ser algo maior, voltado para o benefício dos usuários.

O capital que faz estas empresas funcionarem é o mesmo que faz gerarem milhares de empregos, o que também é uma forma de cumprir com a sua responsabilidade social. Por isto ao mesmo tempo em que não podem abandonar a idéia do lucro, não podem utilizar tal pensamento para querer por fim a um benefício que faz tanto bem para uma parcela tão necessitada de ajuda. Além do que, existem outras formas de buscar um ajuste ao equilíbrio financeiro dos contratos, seja através da renegociação dos contratos, seja por outra forma. Mas que nunca se ataque ao benefício concedido em nome do bem estar e do respeito a dignidade de uma faixa da população tão sofrida.

\section{4: A Posição do STF}

Como já foi dito anteriormente, a questão da concessão por parte do Estado do benefício da gratuidade de transporte para os idosos em transporte coletivo é uma questão que causa enorme polêmica. Inúmeras proposituras de Ação Direta de Inconstitucionalidade são feitas ao Supremo Tribunal Federal, em sede de controle concentrado de constitucionalidade, para argüir a inconstitucionalidade do Artigo 39 do Estatuto do Idoso, que veio a regulamentar tal benefício, já presente no ordenamento jurídico nacional através do Artigo 230 § da Constituição Federal de 1988.

Optamos por analisar a posição mais recente do STF em relação a esta matéria e que veio a ser considerada como a posição definidora acerca deste assunto. Trata-se da ADIN 3768, que foi relatada pela Exma. Ministra Carmem Lúcia. Esta ADIN foi proposta pela Associação Nacional de Empresas de Transportes Urbanos. Trata-se de um sujeito legitimado para propor uma Ação Direta de Inconstitucionalidade conforme previsão constitucional do Artigo 103, IX da Constituição Federal de $1988^{86}$,

\footnotetext{
${ }^{86}$ Artigo 103: São legitimados para propor Ação Direta de Inconstitucionalidade... IX - Confederações Sindicais e Entidades de Classe de Âmbito Nacional
} 
cumprindo todos os requisitos ${ }^{87}$ para propor uma ADIN.

Os argumentos expostos na defesa da inconstitucionalidade do artigo 39 do Estatuto do Idoso já foram aqui citados e contraditados nesta obra. Consistem na idéia da imposição de onerosidade excessiva por parte do Estado aqueles que detêm o direito de explorar as linhas de transporte coletivo municipal. Alegam que a obrigação de prestar assistência aos idosos seria do Poder Público local. O que não se poderia fazer é,se aproveitando da previsão legal do artigo 30, IV, da Constituição de 1988, delegar a obrigação de prestar assistência aos idosos, junto com a prestação de serviços, sem haver qualquer previsão expressa sobre esta possibilidade.

Os advogados da associação afirmam que a obrigatoriedade de realizar esta prestação positiva não se transfere para as Empresas. Afirmam ainda, que se este não for o entendimento do STF, que se deva então discutir a questão das despesas geradas pelo benefício oferecido.

A autora argumenta não ser possível que as empresas de transporte coletivo venham a arcar com despesas extras àquelas previstas no contrato de concessão, o que quebraria o equilíbrio econômico-financeiro do contrato $^{88}$. Portanto, a Associação Nacional de Transportes Urbanos passa a discutir a necessidade de ser criada uma compensação por parte do Estado para harmonizar o prejuízo das empresas.

Ao terminar sua exordial, a autora lista uma série de pedidos alternativos, dentre os quais se destaca o pedido pela declaração da inconstitucionalidade do Artigo 39 do Estatuto do Idoso de forma completa, por causa da imposição da prestação positiva, cujo dever de realizá-la era do Estado. Caso não haja deferimento do pedido, busca que tal dispositivo não se aplique enquanto não houver lei federal que venha a tratar de mecanismos de compensação destas empresas por causa da gratuidade concedida.

O Supremo decidiu esta questão recentemente, no dia 20/09/2007, e

\footnotetext{
${ }^{87}$ Dentre os requisitos de legitimação destacam-se estar em funcionamento a mais de um ano, ter pertinência temática com a questão e representatividade no país.

${ }^{88}$ Artigo 37 XXI da Constituição Federal de 1988
} 
por 9 votos a 1,decidiu pela constitucionalidade do artigo 39 da Lei 10.741/03.A interpretação do Supremo foi pela necessidade de se considerar a matéria como constitucional pois não poderíamos colocar um direito social tão importante como este ,posicionado hierarquicamente na mesma posição que uma mera cláusula econômica do contrato. Somente o Ministro Marco Aurélio Mello ${ }^{89}$ foi favorável a parte autora, ainda que optasse pela não decretação da inconstitucionalidade do artigo.

A Ministra Carmem Lucia, em seu brilhante voto, afirma que a gratuidade concedida pelo Estado nada mais é que uma forma encontrada pelo Poder Público para tentar compensar o abandono que essa parcela da população vive. O transporte coletivo urbano é usado justamente pelas camadas mais desfavorecidas da população e que, por isso, a gratuidade representaria o respeito aos direitos e garantias fundamentais exigidos do Estado no tratamento aos idosos.

O Supremo decide que não faz parte de sua competência determinar se a concessão da gratuidade traz desequilíbrio financeiro ao contrato. As empresas têm como buscar dentro do Poder Judiciário mecanismos que alterem o contrato devido a esse suposto desequilíbrio do contrato. Qualquer manifestação contrária estaria impedindo o uso deste direito.

O Supremo resolveu a questão da constitucionalidade do Artigo 39 do Estatuto do Idoso. Com esta decisão, os idosos estão livres para exercer seu direito a gratuidade. Qualquer forma de impedimento a este exercício, imposta pelas empresas de transporte coletivo, deve ser considerada um abuso por parte das mesmas, devendo ser reprimida por força policial.

\footnotetext{
${ }^{89}$ O voto contrário foi do EXMO.SR. Ministro Marco Aurélio Mello. Não entende como inconstitucional o art.39 do Estatuto do Idoso. O ilustre Ministro decide por uma nova interpretação sobre este benefício, para que se determinem os responsáveis pelas despesas geradas com a concessão da gratuidade. Ao se omitir sobre os responsáveis pelas despesas, o Estado estaria transferindo,de forma indireta,os custos desta gratuidade para a sociedade,uma vez que os empresários do setor de transporte teriam o direito de distribuir os custos, no preço das tarifas.Em seu voto,entende que o Estado estaria onerando excessivamente as empresas através da concessão deste benefício,o que seria uma forma de desrespeito ao princípio da livre iniciativa. Diante desse entendimento, o Ministro votou por uma nova interpretação constitucional, excluindo aquelas que afastem o ônus da Administração pública em compensar a gratuidade.
} 


\section{Capítulo 8: Conclusão}

Após uma longa análise, feita durante este trabalho, acerca da questão da constitucionalidade do Artigo 39 do Estatuto do Idoso, que concede aos idosos o benefício da gratuidade das passagens nos transportes urbanos coletivos, podemos chegar a uma importante conclusão. Acima de qualquer questão sobre a constitucionalidade, vale ressaltar a importância da presença do Estado dentro da sociedade, a fim de sanar os diversos problemas sociais pelos quais passamos nos dias de hoje.

Muitos destes problemas têm uma única origem: o abandono do Estado para com os cidadãos. Por isto, percebemos ser cada vez mais importante que o Estado passe a atuar de forma a sanar estes tipos de problemas. Daí, a necessidade de se criar cada vez mais ações afirmativas, concessão de benefícios, entre outros meios, de forma a garantir uma vida digna para estas vítimas do abandono do Poder Público.

Esses mesmos contornos podem ser traçados para definir a atuação do Estado perante os idosos. Como já restou aqui demonstrado, os idosos são uma das parcelas mais carentes de nossa sociedade. Quem muito trabalhou e ajudou a construir um pouquinho de nosso país, muitas vezes vive os últimos momentos de sua vida abandonado pela sua família, pelo Estado e pela sociedade. O abandono familiar obriga muitos idosos a viverem a solidão de um asilo. $\mathrm{O}$ esquecimento por parte do Estado surge no momento que o Poder Público não fornece serviços de atendimento de qualidade ao idoso e ainda os brinda com proventos de aposentadoria muito baixos, que não são capazes de suprir as suas necessidades. Quanto a sociedade, ao discriminar os idosos, ao não os acolherem nas dificuldades de suas limitações, trata estes indivíduos como se não fizessem parte da comunidade.

A concessão da gratuidade para os idosos é um pequeno gesto por parte do Estado, mas representa uma grande mudança de atitude por parte do Poder Público. Representa a consagração do Princípio da Dignidade da Pessoa Humana previsto no ordenamento jurídico nacional. Afinal, é 
voltada para o respeito e a preservação destes valores dentro dos indivíduos, que deve ser a atuação do Estado.

A dignidade humana é um valor pessoal, quase que espiritual. É verdade que cada pessoa tem livre arbítrio para decidir se o caminho escolhido é ofensivo ou não aos seus padrões pessoais. É o respeito pessoal que cada um deve ter para com sua dignidade. Porém, existe um conjunto de padrões e regras que devem ser respeitadas por todos.

Assim é a atuação do Estado, no caso da gratuidade e em todos os tipos de ação afirmativa que vier a praticar em favor dos membros da sociedade. Cabe ao Estado assegurar para todas as pessoas, a necessária estima aos seus valores, que elas devem manter como seres humanos. Desta forma, todo o pensamento do Poder Público deve estar voltado para garantir condições dignas para todos. Em especial, esta atuação deve se voltar àqueles que são mais necessitados de ajuda, como são os idosos brasileiros. Toda esta ajuda deve ser feita com base na obrigação do Estado de privilegiar as garantias e os direitos fundamentais desses indivíduos, que servem de base para que se proteja e se amplie a dignidade humana. Afinal, uma pessoa quando lhe tem retirada a dignidade, perde o seu maior bem.

Quanto aos aspectos legais, nos parece irretocável a concessão do benefício da gratuidade nos transportes coletivos para os idosos brasileiros. O tão questionado Artigo 39 do Estatuto do Idoso nada mais é do que a forma encontrada pelo legislador para regulamentar algo que até então ficava restrito a esfera legal, sem qualquer tipo de regulamentação para sua aplicabilidade.

A Constituição Federal de 1988 é a grande fundamentadora para este benefício. A partir de 1988, o constituinte passou a tratar de grupos sociais que até então não tinham a atenção merecida por parte do Estado, e que por isso acabavam sofrendo com abusos e discriminações, que acabavam por atacar a sua dignidade, os colocando numa situação de inferioridade perante o resto da sociedade. Vários Exemplos podem ser citados referentes a essas minorias. É o caso das crianças, dos adolescentes, dos índios, e 
principalmente dos idosos. Nestes fundamentos, todas essas minorias passaram a ter uma política estatal voltada para o seu benefício, com legislações específicas regulamentando os direitos e deveres desses grupos.

Foi com esse pensamento que já havia surgido o Estatuto do Índio ${ }^{90}$ o Estatuto da Criança, e finalmente o Estatuto do Idoso. É neste estatuto que temos a regulamentação da concessão de gratuidade nos transportes coletivos.

Quanto aos aspectos levantados neste trabalho para justificar a concessão ou não do benefício, podemos analisar um exemplo claro para aquilo que já aqui chamamos de conflito de forças sociais. De um lado vemos os idosos querendo fazer valer o seu direito concedido pelo legislador. Do outro lado vemos uma série de empresários se preocupando muito mais com a defesa de seu patrimônio, da rentabilidade de seus negócios, do que do benefício que tal concessão traz para uma sociedade já tão abatida por dificuldades quase insuperáveis.

Por isto, não há como negar a validade constitucional do benefício desta gratuidade para os idosos. O pensamento destes empresários não pode estar voltado apenas para o lucro, para o capital. Ele deve estar voltado, principalmente, para a sua Responsabilidade Social. No caso em particular, estas empresas são concessionárias de serviços públicos, e como tal, devem ter seu pensamento voltado para o bem estar do público alvo de seus serviços.

Desta forma, não cabe o argumento já aqui apresentado de que o Estado não pode transferir junto com a competência de prestar o serviço público, a obrigatoriedade de realizar uma ação em benefício de uma parte da população. Afinal,como o próprio texto do Estatuto afirma,é dever de todos cuidar dos idosos de nosso pais. Seja o Estado, sejam as famílias destes idosos, seja a comunidade em geral, TODOS têm a obrigação legal de prestar assistência aos idosos. Não há valor a afirmação que isto é apenas

\footnotetext{
${ }^{90}$ O Estatuto do Índio é anterior a Constituição de 1988 (Lei 6001/73)
} 
um dever do Estado. Cuidar dos Idosos também é obrigação das empresas de transporte público, como parte integrante que são da nossa comunidade.

Desta forma, conclui-se esta obra com a certeza da validade constitucional da atuação do Estado para os idosos. São refutados todo e qualquer argumento até então utilizados para tentar impedir a concessão deste benefício tão importante. Seja através da concessão deste tipo de gratuidade, ou de outras formas de atuação (como a obrigação do Estado de fornecer gratuitamente remédios para os idosos), cabe ao Poder Público agir para resolver os problemas de nossa sociedade.

Com isso, dever sempre estar atento para garantir condições de vida digna para todos, principalmente para os mais necessitados. Através deste tipo de atuação que teremos a consagração deste princípio fundamental que é o do respeito à dignidade da pessoa humana. Somente numa sociedade em que todos tenham sua dignidade respeitada, é que teremos consagrado o verdadeiro sentido do Princípio da Igualdade, que é a igualdade de condições para uma vida digna. 


\section{Bibliografia}

ESPÍNDOLA, Ruy Samuel. Conceito de Princípios Constitucionais. $1^{\mathrm{a}}$ ed. São Paulo: Revista dos Tribunais, 1999.274 p.

SILVA, José Afonso da. Curso de Direito Constitucional Positivo. $16^{\text {a }}$ ed. São Paulo: Malheiros, 1999.871p.

SILVA, José Afonso da. Aplicabilidade das normas constitucionais. $6^{\text {a }}$ Ed., São Paulo, Malheiros, 2003.

MORAES, Maria Celina Bodin de. Danos a pessoa humana: uma leitura civilconstitucional dos danos morais. Rio de Janeiro: Renovar, 2003.

MELLO, Celso Antônio Bandeira. O Conteúdo Jurídico do Princípio da Igualdade. $3^{\mathrm{a}}$ ed. São Paulo: Malheiros, 1993.

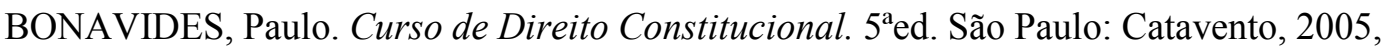
p.

MORAES, Alexandre de. Direito Constitucional. 22a ed. São Paulo: Atlas S.A. 2007 $1012 \mathrm{p}$.

FERNANDES, Daniel André. Os Princípios da Razoabilidade e da Ampla Defesa. $1^{\mathrm{a}}$ ed. Rio de Janeiro: Lúmen Iuris , 2007,133p.

GRAU, Eros Roberto. A Ordem Econômica na Constituição de 1988 (Interpretação e Crítica). $3^{\mathrm{a}}$ ed. São Paulo: RT, 1990, p.

Constituição da República Federativa do Brasil. 12. ${ }^{a}$ ed. RT, 2007,254 p.

Código Civil 9. ${ }^{\mathrm{a}}$ ed.:RT,2007,1888 p.

Revista Brasileira de Ciências Sociais, $n^{\circ} 43$, junho de 2000

www.ibge.gov.br, data de acesso 13/10/2007.

www.senado.gov.br, data de acesso 12/10/2007. 